Article

\title{
Sensitivity of Landsat-8 OLI and TIRS Data to Foliar Properties of Early Stage Bark Beetle (Ips typographus, L.) Infestation
}

\author{
Haidi Abdullah 1,*, Roshanak Darvishzadeh ${ }^{1}$, Andrew K. Skidmore ${ }^{1,2}$ (D) and Marco Heurich ${ }^{3,4}$ \\ 1 Faculty of Geo-Information Science and Earth Observation (ITC), University of Twente, P.O. Box 217, \\ 7500 AE Enschede, The Netherlands; r.darvish@utwente.nl (R.D.); a.k.skidmore@utwente.nl (A.K.S.) \\ 2 Department of Environmental Science, Macquarie University, Sydney, NSW 2106, Australia \\ 3 Department of Conservation and Research, Bavarian Forest National Park, 94481 Grafenau, Germany; \\ Marco.Heurich@npv-bw.bayern.de \\ 4 Chair of Wildlife Ecology and Wildlife Management, University of Freiburg, Tennenbacher Straße 4, \\ D-79106 Freiburg, Germany \\ * Correspondence: H.j.Abdullah@utwente.nl
}

Received: 7 January 2019; Accepted: 13 February 2019; Published: 15 February 2019

\begin{abstract}
In this study, the early stage of European spruce bark beetle (Ips typographus, L.) infestation (so-called green attack) is investigated using Landsat-8 optical and thermal data. We conducted an extensive field survey in June and the beginning of July 2016, to collect field data measurements from several infested and healthy trees in the Bavarian Forest National Park (BFNP), Germany. In total, 157 trees were selected, and leaf traits (i.e. stomatal conductance, chlorophyll fluorescence, and water content) were measured. Three Landsat- 8 images from May, July, and August 2016 were studied, representing an early stage, advanced stage, and post-infestation, respectively. Spectral vegetation indices (SVIs) sensitive to the measured traits were calculated from the optical domain (VIS, NIR, and SWIR), and canopy surface temperature (CST) was calculated from the thermal infrared band using the mono-window algorithm. The leaf traits were used to examine the impact of bark beetle infestation on the infested trees and to explore the link between these traits and remote sensing data (CST and SVIs). The differences between healthy and infested samples regarding measured leaf traits were assessed using Student's $t$ test. The relative importance of the CST and SVIs for estimating measured leaf traits was evaluated based on the variable importance in projection (VIP) obtained from the partial least squares regression (PLSR) analysis. A temporal comparison was then made for SVIs with a VIP > 1, including CST, using statistical significance tests. The clustering method using a principal components analysis (PCA) was used to examine visually how well the two groups of sample plots (healthy and infested) are separated in 2-D space based on principal component scores. Finally, linear regression (LR) was used to generate the leaf traits maps using the SVI that have highest VIP score and then used to produce a stress map for the study area. The results revealed that all measured leaf traits were significantly different $(p<0.05)$ between healthy versus infested samples. Moreover, the study showed that CST was superior to the SVIs in detecting subtle canopy changes due to bark beetle infestation for the three months considered in this study. The results showed that CST is an essential variable for estimating measured leaf traits with VIP $>1$, improving the results of clustering when used with other SVIs. Likewise, the stress map produced by CST and leaf traits well presented the infestation areas at the green attacked stage. The new insight offered by this study is that the stress induced by the early stage of bark beetle infestation is more pronounced by Landsat- 8 thermal bands than the SVIs calculated from its optical bands. The potential of CST in detecting the green attack stage would have positive implications for forest practice.
\end{abstract}


Keywords: bark beetle (Ips typographus, L.); green attack; Landsat-8; canopy surface temperature; spectral vegetation indices

\section{Introduction}

Forests are important ecosystem with economical, social, and ecological values. The economic value of timber in a forest is typically threatened by natural disturbances such as fire, drought, wind, snow, and insect or disease outbreaks [1,2]. In Europe, the European spruce bark beetle (Ips typographus, L.) is a common disturbance agent in forests dominated by Norway spruce (Picea abies) [3]. Bark beetle infestation extends across ten million hectares of trees in Europe. Much public money has been invested to compensate forest owners for their economic loss and for the cost of reforestation [4-6]. In addition to the negative impact on timber production, bark beetles can also have a positive impact on the ecosystem by providing a suitable habitat in the form of opening forest canopy, increasing habitat heterogeneity and biodiversity, all of which enhance the survival of other species $[7,8]$.

The principle of bark beetles killing host trees has been well described in Wermelinger [9]. After a successful attack, the trees change colour in three stages; referred to as green, red, and grey attack, respectively $[9,10]$. The green attack is the early stage of bark beetle infestation in which the colonised trees are yet to show distinct symptoms observable by the human eye [11,12]. A red-attack is evidence of the advanced stage of bark beetle infestation, in which the attacked trees develop stress symptoms involving turning the colour of their needles from green to yellow to red-brown. Subsequently, the needles fall from the infested trees, and only the grey bark remains; hence, this stage is termed 'grey attack' [13].

Detection of bark beetle infestation at the green attack stage means locating infested trees at the stage where the beetle larvae are still within the tree. Effective measures to manage the beetles can then be undertaken. This will ultimately help reduce the number of infested trees, lessening the economic loss. Visual inspections during field surveys and pheromone traps have traditionally been used to detect bark beetle infestations in Norway's spruce forests. However, these methods are subjective, very laborious, costly, and only able to cover relatively small areas. Remote sensing presents an alternative to existing methods for monitoring and detecting infestations on large spatial scales [14]. To date, remote sensing data have been successfully used to detect the advanced stages (red and grey attacks) of bark beetle infestation.

For example, many studies have employed spectral vegetation indices (SVIs) from low-to-medium resolution satellite data to detect the advanced stages of bark beetle infestation (red and grey attack) [12,15-19]; however, to date, the identification of European spruce bark beetle (Ips typographus, L.) green attack has been less satisfactory due to many biological, technical and logistical constraints/limitations. These issues include the flight activity of the bark beetle, the time duration required for the colonisation process and the period when the infested trees have yet to show distinct symptoms capable of being observed by human eye. Hence, it is important to consider biological as well as logistical factors when using remotely sensed data to detect bark beetle green attack [20].

There are very few studies that have paid particular attention to investigating the impact of bark beetle green attack on biochemical properties and physiological status of infested trees. However, they studied different beetle (mountain pine beetle) and tree (lodgepole pine) species. For example, Yamaoka et al. [21] documented a decline in sapwood moisture content resulting from mountain pine beetle attack. Likewise, Cheng et al. [22] revealed water deficit and changes in chlorophyll content of artificially stressed pine trees by mountain pine beetle. They also identified the wavelength range between $950 \mathrm{~nm}$ and $1390 \mathrm{~nm}$ asa good spectral region able to separate healthy from green attacked trees. In general, moisture stress in vegetation may result in non-visual symptoms that are detectable with remote sensing data, particularly in the shortwave and thermal infrared regions, where water 
absorption features exist [23-26]. However, the majority of the studies on bark beetle (either mountain pine beetle or spruce bark beetle) green attack detection with remotely sensed data have mainly utilised optical remote sensing data (Figure 1). There are few published examples of studies which investigate the use of temperature, and none which focus on the impact of European spruce bark beetle infestation on biochemical properties and physiological status of infested trees in the TIR domain. To our knowledge, only one study, by Hais and Kučera [27], has investigated the impact of bark beetle (Ips typographus, L.) infestation at the advanced stages (Gray attack) on surface temperature using thermal infrared (TIR) data. Their study examined the effect of spruce bark beetle infestation and clear-cutting on surface temperature between 1987 and 2002 in the central part of Sumava National Park in the Czech Republic. Further, Sprintsin et al. [28] used the surface temperature calculated from the Landsat 7 ETM+ to detect an early stage of mountain pine beetle infestation in British Columbia. Although Sprintsin, Chen, and Czurylowicz [28] suggested that temperature condition indices (TCI) used in their study have the potential to differentiate between healthy and green attacked pine they could not validate their results due to lack of ground reference data for their green attacked study areas.

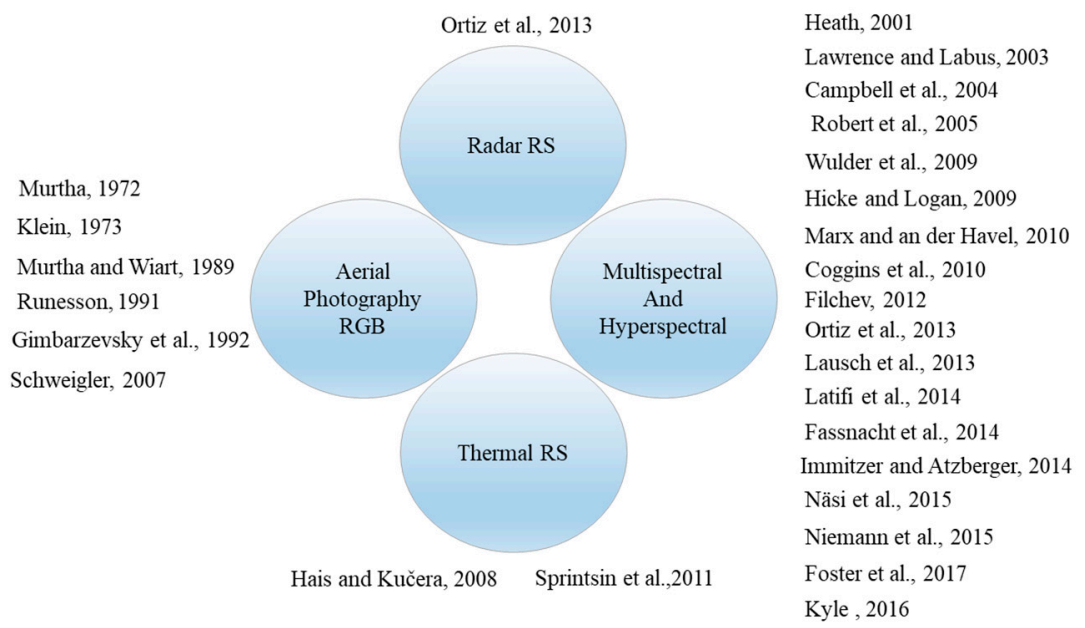

Figure 1. Studies that have used remote sensing data to attempt detecting bark beetle infestation at the green attack stage.

Numerous studies have shown the significant potential of TIR data to elucidate plant biophysical and biochemical properties [29-31]. For example, the primary absorption feature that is associated with leaf water content can be observed in both shortwave and thermal infrared regions (Table 1) [32,33]. As such, several studies have shown that TIR data have great potential to detect plant diseases and pathogens before the plants develop visual stress symptoms [34-38]. Moreover, retrieving the canopy surface temperature (CST) from TIR data is widely used to track vegetation water status [39]. The surface temperature is interrelated with plant functions, such as evapotranspiration which is controlled by stomatal conductance [34,40]. Therefore, alterations in these processes will lead to changes in the air and the surface temperature of leaves [41-44]. Furthermore, physiological studies have shown that the reduction of leaf water content disturbs stomatal conductance and leads to an increase in leaf surface temperature [45-47].

In addition to water content and stomatal conductance, recent studies have shown that there is a strong relationship between canopy surface temperature and photosynthetic activity, which can be measured by chlorophyll fluorescence [36]. Chlorophyll fluorescence has been found to be a reliable indicator for examining the impact of different stressors (drought, insect infestation, and pathogens) on plant photosynthesis and the physiological state of vegetation $[48,49]$. When leaf transpiration rate decreases (i.e., by closing stomata) both chlorophyll fluorescence and photosynthetic activity will decrease, while heat dissipation will increase [50]. Hence, chlorophyll fluorescence has been used as a reliable indicator for monitoring plant water stress [21,51]. 
Table 1. The Landsat- 8 sensors, the operational land imager (OLI), and the thermal infrared sensor (TIRS) spectral bands and their spatial resolution.

\begin{tabular}{ccc}
\hline Bands & Wavelength (micrometers) & Resoultion (meters) \\
\hline Band-1 (Coastal aerosol) & $0.43-0.45$ & 30 \\
Band-2 (Blue) & $0.45-0.51$ & 30 \\
Band-3 (Green) & $0.53-0.59$ & 30 \\
Band-4 (Red) & $0.64-0.67$ & 30 \\
Band-5 (Near Infrared -NIR) & $0.85-0.88$ & 30 \\
Band-6 (SWIR-1) & $1.57-1.65$ & 30 \\
Band-7 (SWIR-2) & $2.11-2.29$ & 30 \\
Band-9 (Panchromatic) & $0.50-0.68$ & 15 \\
Band-10 (Cirrus) & $1.36-1.38$ & 30 \\
Band-11 (Thermal infrared-TIRS1) & $10.60-11.19$ & 100 (resampled to 30) \\
Band-12 (Thermal infrared-TIRS2) & $11.50-12.51$ & 100 (resampled to 30) \\
\hline
\end{tabular}

In this study, for the first time, we sought to explore and compare the potential of both optical and thermal infrared (TIR) data from Landsat- 8 for detection of pre-visual symptoms induced by European spruce bark beetle green attack. We studied the impact of spruce bark beetle green attack on leaf properties (foliar stomatal conductance, chlorophyll fluorescence, and water content). To do this, canopy surface temperature (CST) and spectral vegetation indices (SVIs) were calculated using three Landsat-8 images for May, July, and August 2016, as these months, represent the time of early, advanced, and after spruce bark beetle green infestation, respectively. Our study benefits from valuable in situ measurements of leaf traits at the time of infestation that have been used to explain the impact of bark beetle attacks on Landsat 8 optical and TIR data. Our objectives were as follow: (i) to assess the potential of CST and SVIs calculated from Landsat 8 data to differentiate between healthy and infested sample groups; (ii) to study the temporal variation of CST and SVIs under spruce bark beetle infestation; and (iii) to evaluate the utility of CST and a number of SVIs to estimate measured leaf traits within infested and healthy samples.

\section{Materials and Methods}

\subsection{Study Site and In Situ Data Collection}

The field campaign was conducted during June and July 2016 in the Bavarian Forest National Park (BFNP), which is a 24.222 ha forest located in south-eastern Germany along the border with the Czech Republic, between $13^{\circ} 12^{\prime} 9^{\prime \prime}$ E (longitude) and $49^{\circ} 3^{\prime} 19^{\prime \prime} \mathrm{N}$ (latitude) (Figure 2). The BFNP was established in 1970, and significantly extended in 1997. Depending on the elevation within the BFNP, which ranges from $600 \mathrm{~m}$ to $1453 \mathrm{~m}$, the mean annual temperature fluctuates between $3.5^{\circ} \mathrm{C}$ and $9{ }^{\circ} \mathrm{C}$, and the total annual precipitation varies from $900 \mathrm{~mm}$ to $1800 \mathrm{~mm}[52,53]$. The first bark beetle infestations began in 1984 and, to date, more than 7000 ha have been affected. The strict non-intervention policy of the National Park offers the possibility of studying bark beetle dynamics without human interference [52,54].

We sampled trees from healthy stands and stands with trees freshly infested by the bark beetle. For the healthy stands, we randomly selected plots $(30 \mathrm{~m} \times 30 \mathrm{~m})$ from all over the national park. To select the green attacked trees, we conducted an extensive field survey to search for dry brown powder around the trees. Care was taken to only consider those plots with all trees freshly infested or which were dominated $(80 \%)$ by freshly green-attack trees. In this way, we were assured that the extracted remote sensing signature from these plots would not have mixed effects from the attacked trees of previous years. In total, 40 healthy and 21 infested plots were sampled. The centre of each plot was measured using Differential Global Positioning System (DGPS) Leica GPS 1200 (Leica Geosystems AG, Heerbrugg, Switzerland) with an accuracy of better than $1 \mathrm{~m}$ after post-processing. Each of 61 selected plots measured $30 \times 30 \mathrm{~m}$ to encapsulate the spatial resolution of a Landsat- 8 data, which 
allows for a $30 \mathrm{~m}$ radius buffer zone around the 'central pixel' location for uncertainty in spatial registration of image pixels. By doing this we minimized the potentially confounding influence (mixed pixels) of green attacked Norway spruce trees.

From each plot, three to five trees were selected as representative for the plot. Since the height of Norway spruce trees reaches 25 to $30 \mathrm{~m}$, we used a crossbow to shoot an arrow with a fishing line attached to a branch with sunlit leaves. The fishing line was used to feed a rope over the targeted branch from the upper canopy. Once the rope was in place, the branch was pulled down gently until it broke off. Full details regarding the use of the crossbow can be found in Ali et al. [55]. On average two to three branches, exposed to sunlight, were taken from the upper part of each tree. Next, needle samples were taken from the collected branches to measures leaf traits.

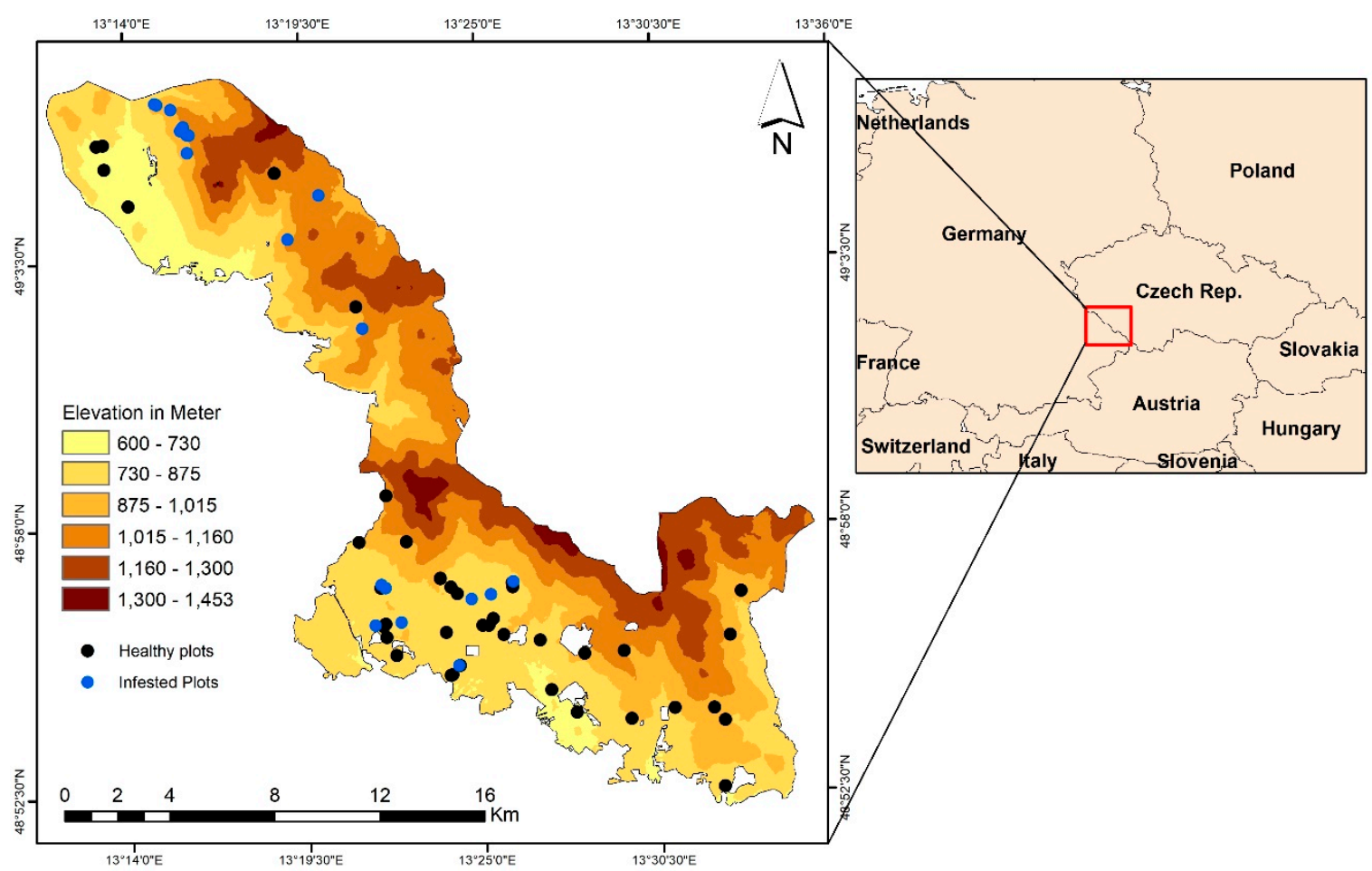

Figure 2. The location of Bavarian Forest National Park in Central Europe.

\subsection{Measurement of Leaf Properties}

In this study, a steady-state instrument SC-1 Leaf Porometer (Decagon Devices Inc., Pullman, WA, USA) was used to measure the needle stomatal conductance. This instrument computes stomatal conductance using a leaf clip chamber that can monitor the relative humidity $(\mathrm{RH} \%)$ released from the leaf stomata. To measure the stomata, a number of needles were gently attached to cover the chamber port. Since stomata are sensitive to environmental conditions and physical stress, all the measurements were taken under similar environmental conditions (clear sky, between 11 am to 3 pm local time). An average of three to four measurements was taken for each sampled tree within each plot (SC-1 Operator's Manual, 2016).

Immediately after the stomata measurement, a chlorophyll content meter CCM-330 (Opti-Sciences, Inc., Hudson, NH, USA) was used to measure the chlorophyll fluorescence ratio (CFR). This instrument uses the emission ratio of fluorescence at both the red $(700 \mathrm{~nm})$ and the far red $(735 \mathrm{~nm})$ part of the electromagnetic spectrum, as proposed by Gitelson et al. [56]. On average ten readings were taken per sample from each branch. Then, the leaf water content $\left(\mathrm{CW}, \mathrm{mg} / \mathrm{cm}^{2}\right)$ was computed using fresh and dry weight. To do this, three grams of the freshly harvested needles were weighed from each sample. A portable leaf area meter (AM-350) was used to measure the total needles' surface area for each of the three grams considered. Norway spruce needles are cylindrical and, therefore, this surface area was 
multiplied by a universal conversion factor of 2.57 [57]. Then, to acquire the hemispherical-surface projection of the sample surface needles, the total area obtained was divided by 2 . Finally, the needle samples were oven dried for $72 \mathrm{~h}$ at $75^{\circ} \mathrm{C}$, and the dried weight of each sample was measured. The leaf water content $(\mathrm{Cw})$ was computed using the following equation [58]:

$$
\mathrm{Cw}=\frac{\mathrm{Wf}-\mathrm{Wd}}{\mathrm{A}}
$$

where Wf and Wd are the fresh and dry weight, respectively, and A is the sample leaf area.

\subsection{Landsat-8 Imagery and Pre-Processing}

Cloud-free Landsat-8 images were obtained from the USGS Global Visualization Viewer (http://glovis.usgs.gov/) for the months May, July, and August 2016. According to the Bavarian Forest National Park authorities, the bark beetles of the infestation in 2016 had started to swarm on 10 May 2016. Therefore, the May image was designated as the early stage of bark beetle infestation.

Landsat- 8 has two sensors called OLI and TIRS. The OLI sensor collects data from nine spectral bands ranging from $0.43-2.29 \mathrm{~nm}$ with a $30 \mathrm{~m}$ spatial resolution, while the TIRS sensor collects data from two thermal bands ranging from 10.6-12.5 nm with a $100 \mathrm{~m}$ spatial resolution resampled to $30 \mathrm{~m}$ in the delivered data product (Table 1).

For both the OLI and the TIRS sensor, radiance values were calculated, using the coefficient supplied by USGS. Secondly, for OLI data, a radiometric calibration was applied to convert the radiance value to top-of-atmosphere (TOA) reflectance. Then, MODTRAN4-based atmospheric correction software (FLAASH) was used to convert the TOA Reflectance to surface reflectance [59]. Full details regarding the use of FLAASH can be found in [60]. Finally, the reflectance values of the infested and healthy plots were extracted from the Landsat- 8 scenes and were used for further analysis.

\subsubsection{Spectral Vegetation Indices}

Several spectral vegetation indices exist in the literature that are used for estimation of vegetation biochemical properties [61-63]. In this study, spectral vegetation indices linked to measured leaf traits were calculated from the spectral reflectance data collected from the Landsat OLI sensor. In previous work [64-66], the selected SVIs have shown sensitivity to stress-induced variations in chlorophyll and also water content, which are all important indicators of tree health. This sensitivity could potentially be used to assess stomatal closure and tree water stress due to insect infestation. The mathematical transformation for computing these vegetation indices is given in Table 2.

Table 2. List of spectral vegetation indices calculated from Landsat-8 optical bands.

\begin{tabular}{|c|c|c|c|}
\hline Index & Formula & Full Name & Reference \\
\hline Cigreen & (NIR/Green) - 1 & Chlorophyll index green & [67] \\
\hline CVI & NIR $\times(\operatorname{Red} /$ Green2) & Chlorophyll vegetation index & {$[67]$} \\
\hline CI & $($ Red - Blue $) /$ Red & Coloration index & [68] \\
\hline GVI & NIR - Green & Green difference vegetation index & [69] \\
\hline DVI & $2.4 \times(\mathrm{NIR}-\mathrm{Red})$ & Difference vegetation index & [70] \\
\hline GVMI & {$[(\mathrm{NIR}+0.1)-(\mathrm{SWIR}+0.02)] /[(\mathrm{NIR}+0.1)+(\mathrm{SWIR}+0.02)]$} & Global vegetation moisture index & [71] \\
\hline GARI & {$[$ NIR $-($ Green $-($ Blue - Red $))] /[$ NIR $-($ Green $+($ Blue - Red $))]$} & $\begin{array}{c}\text { Green atmospherically resistant } \\
\text { vegetation index }\end{array}$ & [72] \\
\hline GLI & {$[2 \times($ Green - Red - Blue $)] /[2 \times($ Green + Red + Blue $)]$} & Green leaf index & [73] \\
\hline LWCI & {$[\log (1-(\mathrm{NIR}-\mathrm{SWIR}))] /[\log (1-(\mathrm{NIR}+\mathrm{SWIR}))]$} & Leaf water content index & [74] \\
\hline NLI & $(\mathrm{NIR}-\mathrm{Red}) /(\mathrm{NIR}+\mathrm{Red})$ & Nonlinear vegetation index & [75] \\
\hline PVR & $($ Green - Red $) /($ Green + Red $)$ & $\begin{array}{c}\text { Normalized Difference Photosynthetic } \\
\text { vigour ratio }\end{array}$ & [76] \\
\hline SIWSI & (NIR-SWIR)/(NIR + SWIR) & Normalized Difference 860/1640 & [77] \\
\hline BGI & Costal/Green & Blue-green pigment index & This study \\
\hline RDI & SWIR2/NIR & Ratio Drought Index & [78] \\
\hline NDVI & $(\mathrm{NIR}-\mathrm{Red}) /(\mathrm{NIR}+\mathrm{Red})$ & Normalized difference vegetation index & [79] \\
\hline TNDVI & $\log [(\mathrm{NIR}-\mathrm{Red}) / \mathrm{NIR}+\mathrm{Red}) \times 0.5]$ & Transformed NDVI & {$[80]$} \\
\hline
\end{tabular}




\subsubsection{Canopy Surface Temperature (CST)}

The Landsat-8 TIR sensor provides data from two bands (band 10 and band 11) in the thermal domain. However, band 11 is no longer operational for quantitative analysis, as reported by USGS (https://landsat.usgs.gov/using-usgs-landsat-8-product). Therefore, in our study, band 10 with wavelengths ranging from 10.60 to $11.19 \mathrm{~nm}$ was utilised to retrieve canopy surface temperature CST.

To minimise and reduce the effects of different climatic conditions on CST retrieval, the mono-window algorithm, proposed by Qin et al. [81], was applied. The core of this method is the equation transferring thermal radiance, which converts digital satellite values to a radiometric value [82]. To apply this algorithm, a number of parameters such as emissivity, air transmittance, and effective mean atmospheric temperature are required. The air transmittance and mean atmospheric temperature are estimated using another two additional parameters, namely: air surface temperature and water vapour content. Water vapour was calculated using relative humidity ratio and air surface temperature [83]. The following equations summarise the steps required when using the mono-window algorithm for retrieving CST.

First, digital values (DVs) of band 10 are converted to TOA spectral radiance using the equation:

$$
\mathrm{Ly}=\mathrm{ML} \times \mathrm{Qcal}+\mathrm{AL}
$$

where Ly is TOA spectral radiance received by the sensor measured in $\mathrm{mW} \mathrm{cm}-2 \mathrm{sr}-1 \mu \mathrm{m}-1$; ML is the band specific multiplicative rescaling factor for band 10 equal to 0.0003342 ; Qcal is the actual band 10 digital number $(\mathrm{DN})$, and $\mathrm{AL}$ is a band-specific additive rescaling factor equaling 0.1 . This information was obtained from the metadata file and USGS Landsat-8 product use documentation (https:/ /landsat. usgs.gov/using-usgs-landsat-8-product).

The next step was to convert spectral radiance to satellite brightness temperature (blackbody temperatures) by expressing Planck's function. The equation used was proposed by Markham and Barker (1986):

$$
\mathrm{Bt}=[\mathrm{K} 2 / \log (1+\mathrm{K} 1 / \mathrm{Ly})]-273.15
$$

where $\mathrm{Bt}$ is the satellite brightness temperature in Celsius, $\mathrm{K} 1$ and $\mathrm{K} 2$ are calibration constants (774.89 and 1321.07, respectively) of Landsat-8 representing at-sensor spectral radiances of Landsat TM Band 10, and Ly is the satellite spectral radiance retrieved from Equation (1). The brightness temperature calculated with this second equation is called the top of the atmospheric temperature [84]. The following additional parameters were measured:

\section{Land surface emissivity}

The brightness temperature derived from Equation (2) refers to a blackbody target. Since the target bodies on land surfaces are not perfect blackbodies, the thermal emissivity of the land surface must be retrieved from the area being studied [85]. Several factors such as plant chemical composition and surface roughness affect the estimation of canopy surface emissivity from remote sensing data [86]. Several methods have been proposed to retrieve emissivity from remote sensing data, such as image classification and the NDVI-based threshold approach. Image classification based on Landsat imagery is not an appropriate method for the estimation of land surface emissivity due to the spatial resolution, with one pixel possibly comprising different land cover classes [87]. As a result, the NDVI-based threshold is a more appropriate approach for the calculation of ground emissivity using Landsat imagery [88]. The NDVI-based approach was first proposed by Van de Griend and Owe [89] and was later modified by Valor and Caselles [90]. In this study, we followed the approach by Valor and Caselles [90] using NDVITHM to calculate emissivity for the study area as follows:

$$
\varepsilon=\varepsilon \mathrm{v} \times \mathrm{Pv}+(1-\mathrm{Pv})+4<\mathrm{d} \varepsilon>\mathrm{Pv} \times(1-\mathrm{Pv})
$$


where $\varepsilon$ is the ground emissivity; $\varepsilon v$ is the emissivity for pure vegetation covered area; $d \varepsilon$ is the constant value of topography factor (0.01), and Pv is the proportion of vegetation, obtained from NDVI, based on the following equation proposed by Carlson and Ripley [91]:

$$
\mathrm{Pv}=(\mathrm{NDVI}-\mathrm{NDVIg}) /(\mathrm{NDVIV}-\mathrm{NDVIg})
$$

where $\mathrm{Pv}$ is the proportion of vegetation for each pixel; NDVIg is the NDVI value in bare soil $(\mathrm{NDVI}<0.2$ ); and NDVIv is the NDVI value for purely vegetation-covered areas (NDVI > 0.5). Further details regarding emissivity based NDVI estimation can be found in [92].

\section{Estimation of atmospheric transmittance}

The atmospheric transmittance was estimated using water vapour content based on the formula by Qin, Karnieli, and Berliner [81]:

$$
\mathrm{Wc}=0.0981 \times[10 \times 0.6108 \times \exp ((17.27 \times(\mathrm{T} 0)) \times \mathrm{RH}]+0.1697
$$

where Wc is the water vapour content in $\mathrm{g} / \mathrm{cm}^{2}, \mathrm{~T} 0$ is the near-surface or air temperature in degrees Celsius and RH it is the relative humidity.

Both near-surface temperature and relative humidity $(\mathrm{RH})$ data were obtained from climate-station Waldhäuser located in the BFNP at $950 \mathrm{~m}$ above sea-level on a southwest slope.

Based on the air surface temperature and humidity ratio data from the Waldhäuser station, the water vapour content ranged between 1.6 and $3.0 \mathrm{~g} / \mathrm{cm}^{2}$ with our data being captured in the summertime. Thus, the following formula was used to estimate atmospheric transmittance:

$$
\mathrm{T}=1.031412-0.11536 \times \mathrm{Wc}
$$

where $\mathrm{T}$ is the atmospheric transmittance, and $\mathrm{Wc}_{\mathrm{c}}$ is the estimated water vapour content obtained from the previous equation.

\section{Mean atmospheric temperature}

The final parameter required for the calculation of CST using the mono-window algorithm is mean atmospheric temperature. The Landsat data were captured in May, July and August, 2016, which meant summer conditions. Therefore, the following formula was used to estimate the mean atmospheric temperature [81,93]:

$$
\mathrm{Ta}=[16.0110+0.92621 \times(\mathrm{T} 0)]-273.15
$$

where Ta is the mean atmospheric temperature in degrees Celsius, and T0 is the surface air temperature in Kelvin. Data on air temperature were obtained from the Waldhäuser weather station.

Finally, the mono-window algorithm was employed to retrieve canopy surface temperature over the study area, as follows:

$$
\mathrm{CST}=(\mathrm{A} \times(1-\mathrm{C}-\mathrm{D})+[\mathrm{B} \times(1-\mathrm{C}-\mathrm{D})+\mathrm{C}+\mathrm{D}] \times \mathrm{Bt}-\mathrm{D} \times \mathrm{Ta}) / \mathrm{C}
$$

where CST is the canopy surface temperature in degrees Celsius, Bt which is the effective temperature viewed by the satellite under an assumption of unity emissivity in degrees Celsius, and Ta is the mean atmospheric temperature in degrees Celsius. In addition, the parameters $\mathrm{A}$ and $\mathrm{B}$ have standard values proposed by Qin, Karnieli and Berliner [81] which are -67.355351 and 0.458606 , respectively, while the parameters $\mathrm{C}$ and $\mathrm{D}$ are obtained using the following formulae:

$$
C=\varepsilon \times T
$$


and

$$
\mathrm{D}=(1-\mathrm{T}) \times[1+(1-\varepsilon) \times \mathrm{T}]
$$

where $\varepsilon$ is the emissivity estimated from Equation (3), and $\mathrm{T}$ is the atmospheric transmittance.

\subsection{Statistical Analysis}

To fulfil the objective of this research, three statistical analyses were employed, namely, statistical significance test (Student's $t$ tests), partial least squares regression (PLSR), and principal components analysis (PCA). The Student's $t$ tests were used to assess the impact of bark beetle infestation at the green attack stage on the measured leaf traits (foliar stomatal conductance, chlorophyll fluorescence, and water content) and remote sensing data (SVIs and CST). Next, to identify the key SVIs for estimating the studied leaf traits (foliar stomatal conductance, chlorophyll fluorescence, and water content) variable importance in projection (VIP) was calculated from the PLSR analysis. The VIP scores are useful in understanding $\mathrm{X}$ space predictor variables (SVIs and CST) that best explain dependent $(\mathrm{Y})$ variables (leaf traits). The "VIP method selects those $X$ variables that contribute most to the underlying variation in the $X$ variables. This includes the variation not related to $y$, but describing interferences, that is so-called orthogonal variation." [94] To achieve this, PLSR analysis was employed. The PLSR "is a regression method that takes into account both the variance of the dependent and the predictor variables. It specifies a linear relationship between a set of dependent $(\mathrm{Y})$ variables (leaf traits) and a set of predictor (X) variables." (CST and SVIs) [95]. The PLSR was used for the Landsat-8 image captured in July 2016, as it matched the time of field data collection. Three independent PLSR models were built for each leaf trait separately as well as for each sample group (green attacked and healthy samples). In general, a VIP score $>1$ unit indicates that the contribution of the variable (CST or SVI) was significant, and the greater the VIP value, the larger is the contribution of the variable to the model [96].

Moreover, to investigate the potential of separating healthy plots from infested ones in a 2-D space, the clustering method using PCA was employed. In other words, PCA was used to determine the importance of each SVI for discriminating between healthy and infested plots during all three months considered in this study. PCA is an unsupervised technique and has been successfully used in many remote sensing studies as a data reduction approach [97]. The mean centring and unit variance producer were used to preprocess the data. The SVIs (those having a VIP score higher than one for both healthy and infested sample plots) were treated as independent variables, and for each image date considered in this study, two PCA models were built as follows: (a) a PCA model including all selected SVIs and CST (VIP > 1); (b) a PCA model including only SVIs. This step is essential because it allows us to understand and identify the most effective SVIs in terms of making a significant contribution to discriminating healthy from freshly infested spruce plots (Figure 3).

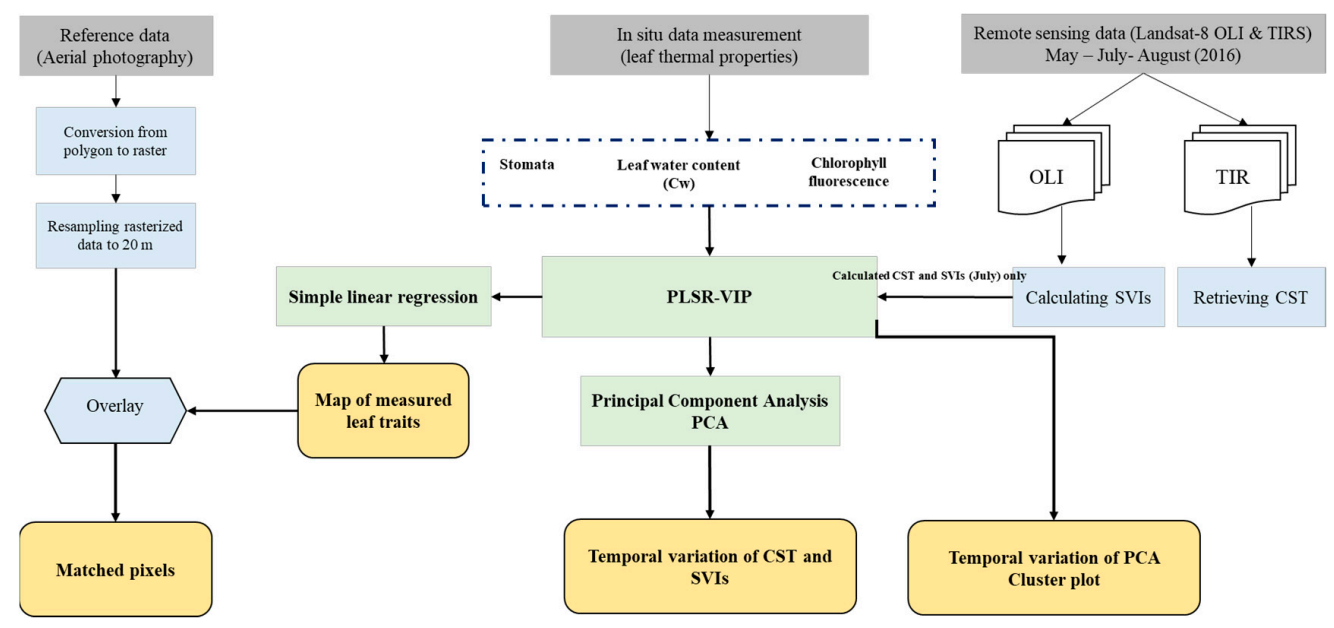

Figure 3. The framework of the research methodology. 
From the selected SVIs, those that have VIP $>1$, a box plot technique was used to explore the temporal variation between healthy and infested plots for all three months considered in this study. The values of SVIs and CST were normalized between 0 and 1 using the MinMax normalisation method.

\subsection{Mapping Bark Beetle Green Attack Infestation}

To generate the map of bark infestation, we considered the SVI with the highest VIP score as the most important variable to estimate studied leaf traits. Linear regression was used to generate maps of the measured leaf traits (foliar stomatal conductance, chlorophyll fluorescence, and water content), and the generated maps of leaf traits were used as a proxy to produce a map of bark beetle green attack. To do this, we classified the produced maps using the range of the leaf traits from the field (Table 3). The final map contains three classes corresponding to the stress intensity in each trait. Following this, to validate the generated map of infestation, ancillary vector-based reference data of the green attacked areas in 2016 were obtained from the Bavarian Forest National Park (BFNP) administration (Abdullah et al., 2018b). The flight on 11 Jun 2017 documented new dead wood (grey attack stage) from the previous year 2016, with reference data collected from airborne colour-infrared (VIS and NIR) aerial images (CIR) with $0.1 \mathrm{~m}$ spatial resolution. Full details about the processing and interpretation of the aerial photography in the BFNP can be found (Heurich et al., 2009; Lausch et al., 2013a). The reference data (ground truth) were in the form of polygons and were rasterised into $30 \mathrm{~m}$ $\times 30 \mathrm{~m}$ grid cells to match with the produced maps from Landsat- 8 SVI. In total, 417 pixels were used as the ground truth data. Furthermore, land cover data obtained from the national park administration were used to mask out non-spruce stands and young stands. This is because bark beetles only infest old and mature Norway spruce (Picea abies (L.) Karst). The masked land cover was overlaid on the classified leaf traits maps in this study (Figure 3). Finally, the total number of pixels (ground truth) located within each (stress class) were extracted and calculated.

Table 3. Stress level categories classified using the range of the leaf traits (leaf water content, stomatal conductance, and chlorophyll fluorescence) from the field, in the Bavarian Forest National Park, July 2016.

\begin{tabular}{cccc}
\hline & Severely Stressed & Moderately Stressed & Healthy \\
\hline Leaf water content $\left(\mathrm{g} / \mathrm{cm}^{2}\right)$ & $<0.0135$ & $0.135-0.0145$ & $>0.0145$ \\
Stomatal conductance $\left(\mathrm{mmol} / \mathrm{m}^{2} \mathrm{~s}\right)$ & $<103$ & $103-120$ & $>120$ \\
Chlorophyll fluorescence ratio & $<1.17$ & $1.17-1.25$ & $>1.25$ \\
\hline
\end{tabular}

\section{Results}

\subsection{The Importance of CST versus SVIs to Estimate Measured Leaf Properties}

Infestation by bark beetle caused substantial changes in all studied leaf traits during the green attack stage. The result of the Student's $t$ test demonstrated a significant difference $(p<0.05)$ between healthy and infested leaves for all the studied leaf traits (chlorophyll fluorescence, leaf water content, and stomatal conductance) (Figure 4). Furthermore, as can be seen from Figure 5, the VIP scores show that CST significantly contributes to the estimation of studied leaf traits (chlorophyll fluorescence, water content, and stomatal conductance) for both healthy and infested plots. However, among the SVIs only five out of 23 had a VIP score above one for both healthy and infested sample plots; these five indices are CIgreen, CVI, CI, NLI, and BGI (Figure 5). The single bands of Landsat-8 showed the lowest VIP score for all measured leaf traits. 

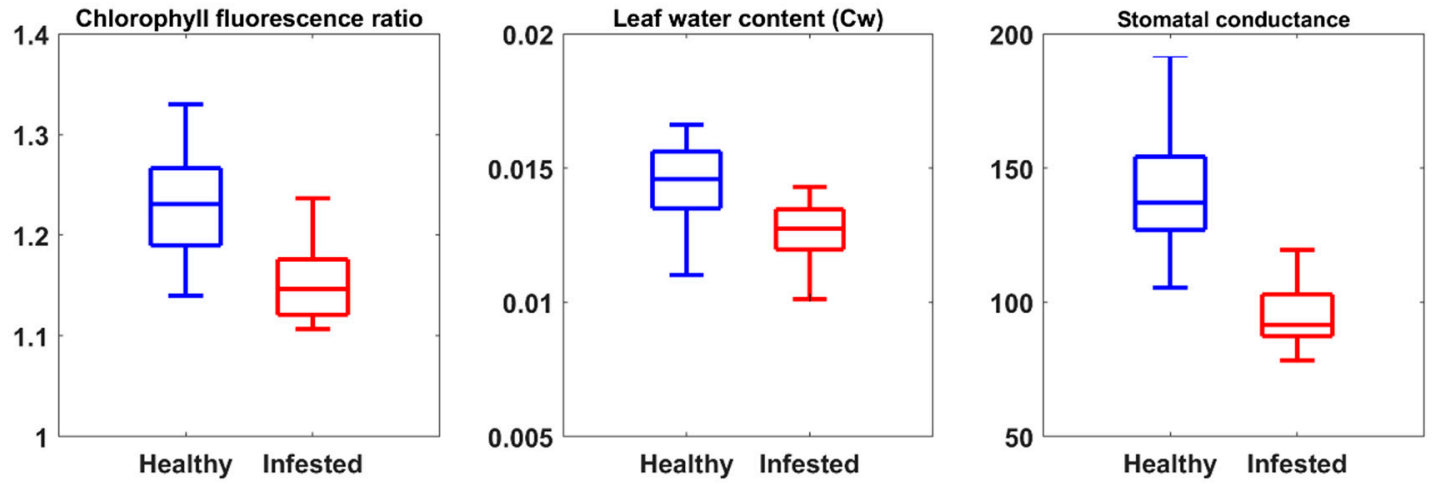

Figure 4. Distribution of measured leaf traits for healthy and infested needles, in the Bavarian Forest National Park, July 2016. There is a significant difference $(p<0.05)$ in all measured leaf traits between healthy and infested samples.
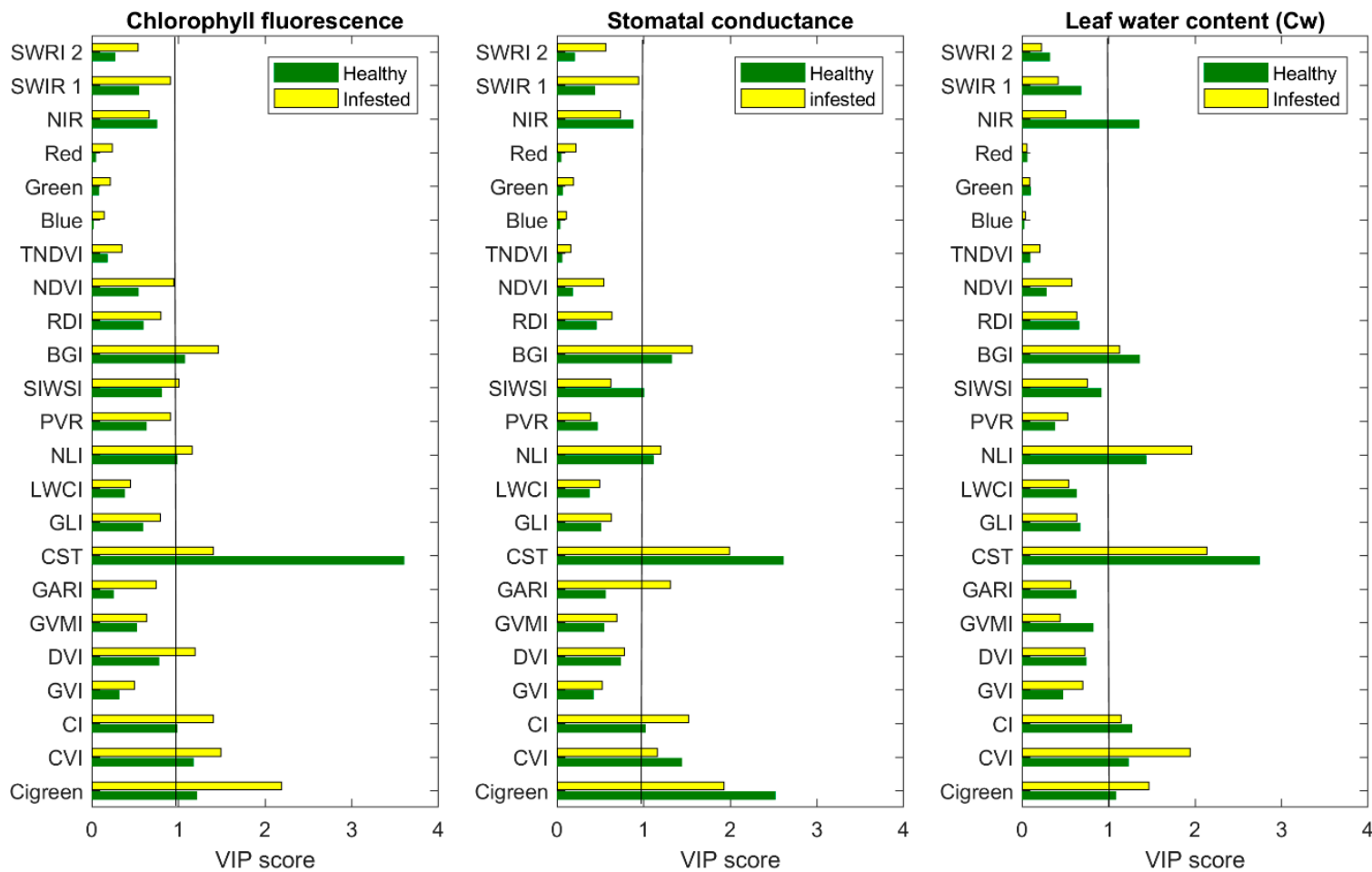

Figure 5. PLSR variable importance in the projection (VIP) for predictor (CST and SVIs) and response variables (measured leaf traits) in the Bavarian Forest National Park, July 2016 (the vertical black line represents $\mathrm{VIP} \geq 1$ ).

\subsection{Temporal Response of CST and SVIs under Spruce Bark Beetle Infestation}

To assess the temporal variation of the CST and those SVIs that obtained a VIP score $>1$, we studied the boxplots for all three months considered in this study. Figure 6 shows a comparative time-series of CST and SVIs for healthy and infested sample plots. As can be seen from this figure, the CST in infested and healthy plots differ from the SVIs by exhibiting increased temperature from the beginning of the infestation in May, whereas almost all other indices show no differences between healthy and infested plots. Similarly, in July, when the infestation is still at its early stage (green attack), CST shows high potential for discriminating between healthy and infested sample plots. However, in August, when the infested plots entered into the advanced stage (in which the infested trees developed stress symptoms by turning their needles' colour from green to yellow to red-brown and can be detected by the human eye), CST as well as CIgreen, NLI, and BGI are significantly different $(p<0.05)$ between healthy and infested plots. 

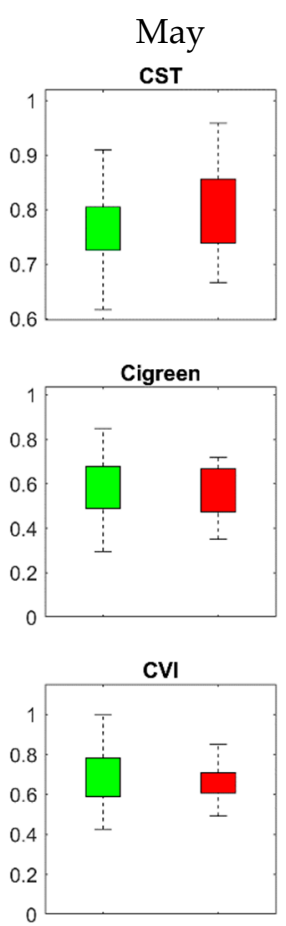

$\mathrm{Cl}$

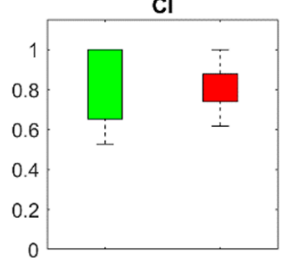

NLI

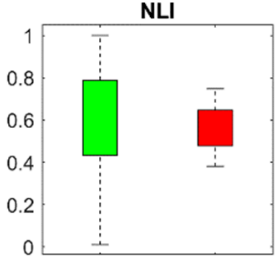

BGI

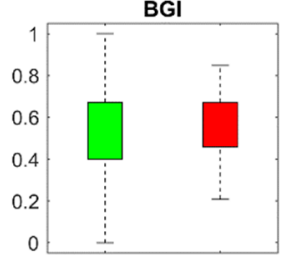

July

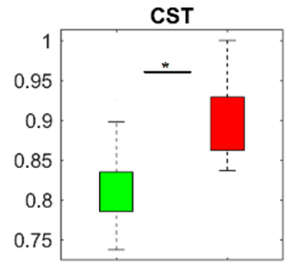

Cigreen

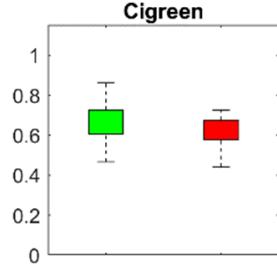

CVI

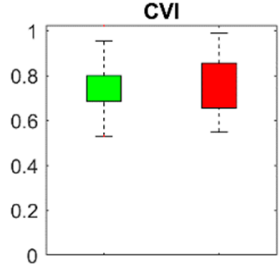

Cl

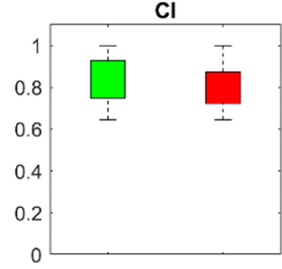

NLI

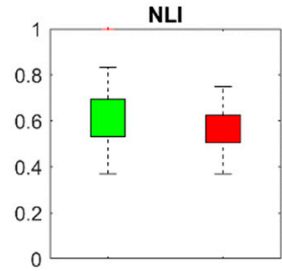

BG

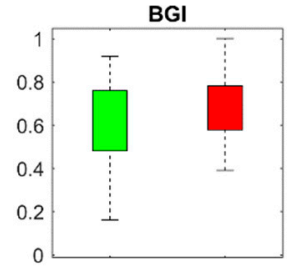

August

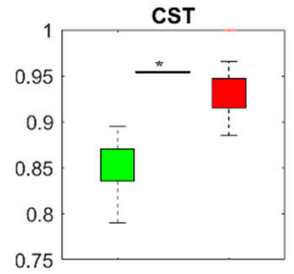

Cigreen

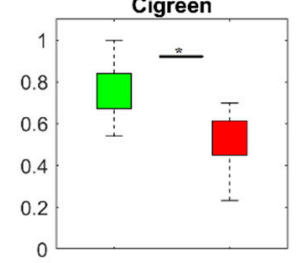

CVI

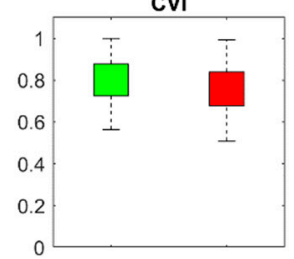

Cl
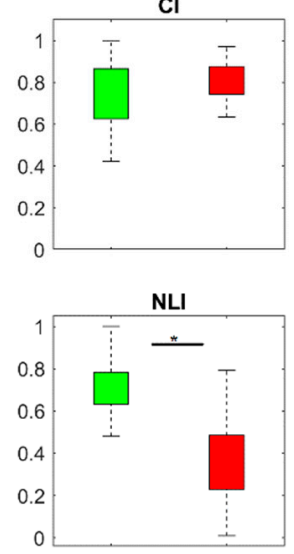

BGI

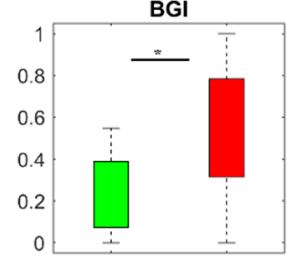

Figure 6. Temporal variation of the SVIs and CST (VIP > 1) for healthy and green attacked sample plots in the Bavarian Forest National Park. Green and red boxes represent healthy and infested plots, respectively. $A$ * indicates the significant difference between healthy and infested plots obtained using Student's $t$ tests.

The selected SVIs, which had a VIP value > 1 (CST, CIgreen, CVI, CI, NLI, and BGI) have been used to build the PCA model. As shown in Figure 7, in May, when the infestation is in its early stage, there is an apparent overlap and mixed scattering between healthy and infested sample plots when SVIs were applied in the model. However, in July and August, when CST is included into the model, the majority of healthy plots tend to be on the negative side of PC1, while the infested plots are relatively scattered on the positive side of PC1. In general, we observed distinct improvement 
to differentiate between healthy and infested plots when both CST and SVIs were used to build the PCA model.

A
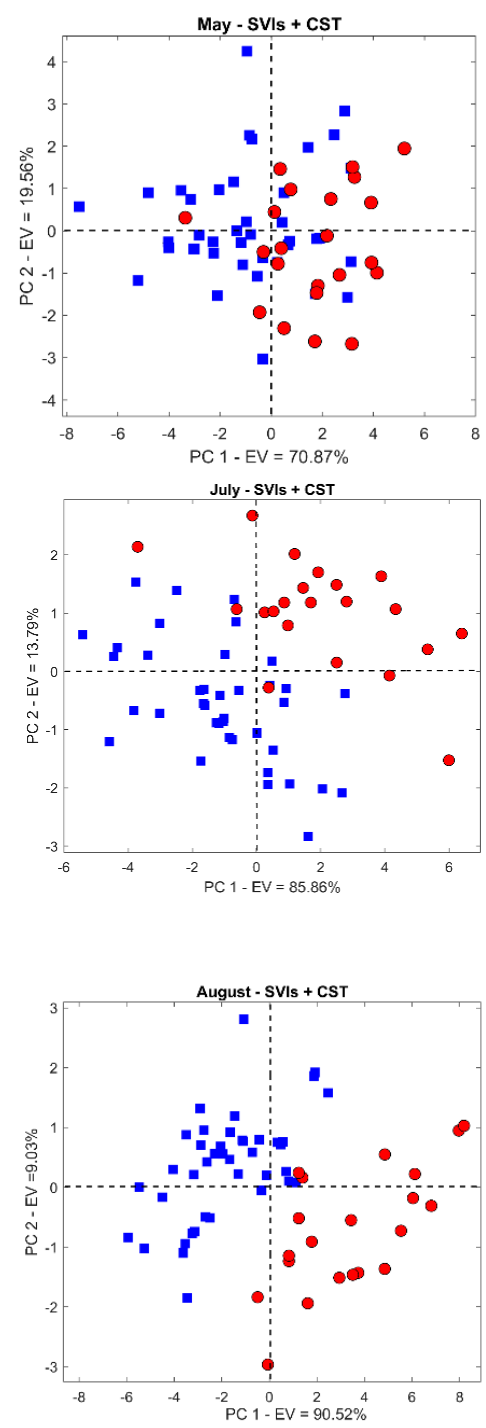

B
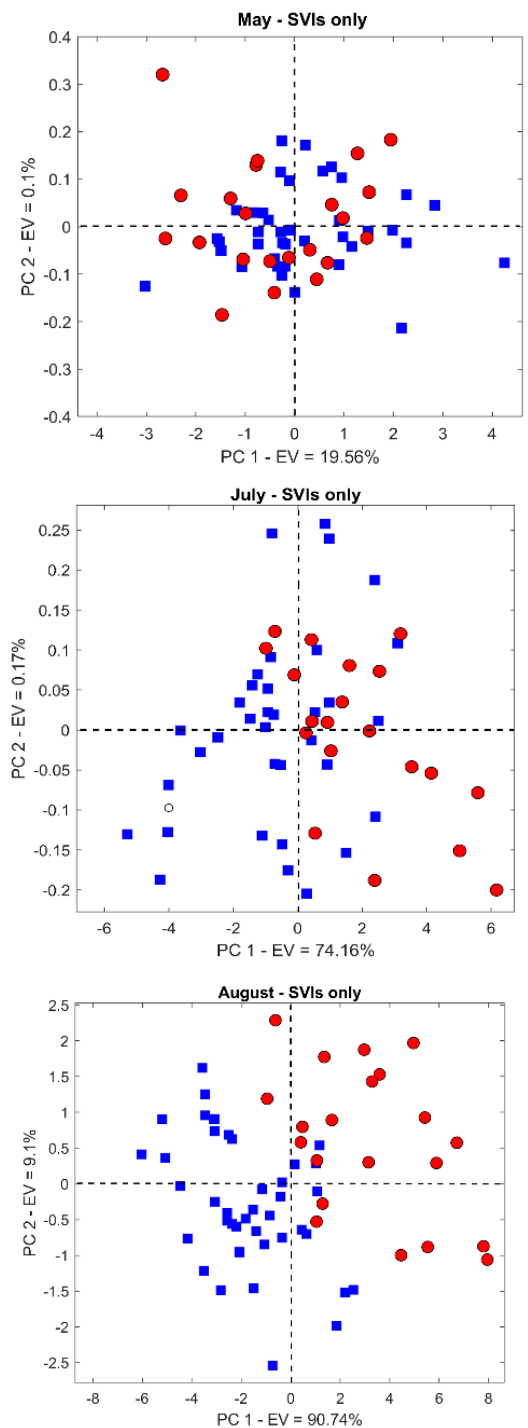

Figure 7. Cluster plots based on the first two principal components (PCs), blue squares and red circles represent healthy and infested plots, respectively. (A) Cluster plots based on all spectral indices VIP $>1$ including CST, and (B) cluster plots based on all spectral indices VIP > 1 excluding CST.

\subsection{Mapping Bark Beetle Green Attack and Validation}

As shown in Figure 5, CST recorded the highest VIP score in all measured leaf traits, and therefore we considered it as the most important variable for predicting studied leaf traits. The CST was then used to estimate leaf traits (foliar stomatal conductance, chlorophyll fluorescence, and water content) and generate maps using the SLR model (Table 4). Following this, based on the defined threshold value (Table 3), stress maps were generated using leaf traits' data. These maps were then overlaid with ground truth reference data (417 pixels) to calculate those pixels located within each stress class. Figure 8 and Table 5 depict those areas (pixels) that were located in each class. As can be seen from Table 5, 274 pixels out of 417 (66\%) from ground truth data were located with the severely stressed class; following this, 89 (21\%) pixels were located in the moderately stressed class and the remaining $54(13 \%)$ pixels where located within the healthy class. 
Table 4. Regression equations between canopy surface temperature (CST) and measured leaf properties.

\begin{tabular}{cc}
\hline Equation No. & Regression Equations \\
\hline 1 & Leaf water content $=-0.0004$ CST +0.0203 \\
2 & Stomatal conductance $=-6.4377$ CST +255.66 \\
3 & Chlorophyll fluorescence $=-0.0264$ CST +1.68 \\
\hline
\end{tabular}

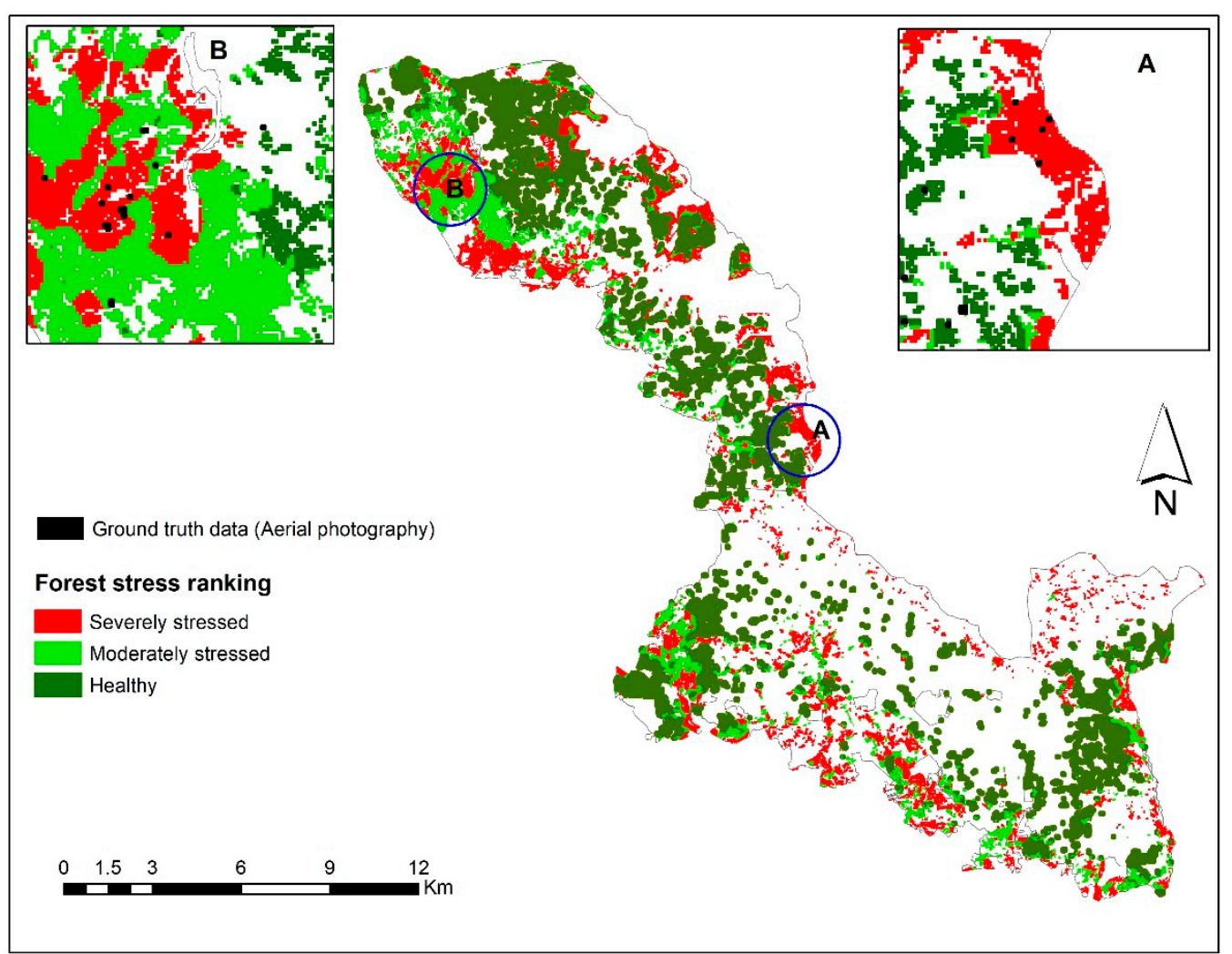

Figure 8. The map showing the distribution of Norway spruce stands under different stress levels in the Bavarian Forest National Park, July 2016. The map was produced using canopy surface temperature and measured leaf traits (foliar stomatal conductance, chlorophyll fluorescence, and water content).

Table 5. Assessment of the generated map using reference data obtained from aerial photography.

\begin{tabular}{cc}
\hline Forest Stress Classes & Pixels Correctly Matched \\
\hline Severely stressed & 274 \\
Moderately stressed & 89 \\
Healthy & 54 \\
\hline
\end{tabular}

Reference pixels (aerial photography) $=417$ pixels $(30 \mathrm{~m})$.

\section{Discussion}

In the present study, for the first time, we assessed the potential of CST and SVIs to discriminate between healthy and green-attacked trees by European spruce bark beetle (Ips typographus, L.). The results confirmed the superiority of CST in discriminating subtle differences between healthy and infested trees, compared to other utilised SVIs at different stages of bark beetle attack. Furthermore, all three considered leaf traits in this study exhibited significant differences $(p<0.05)$ between the two sample groups (healthy and infested), and CST was found to be an essential indicator (VIP $>1$ ) to estimate them.

Of all 23 remote sensing variables (CST, SVIs, and single bands) used, the variable importance in projection (VIP > 1) showed that CST was by far the best at estimating studied leaf traits (Figure 5). 
This result reaffirms findings by [24], who used TIR data obtained fixed-wing UAVs to study thermal water stress over the peach trees. Moreover, apart from the importance of CST in estimating leaf properties, we found that CST better discriminates between infested and healthy trees than other SVIs. In July and August, CST was significantly higher $(p<0.05)$ for the infested plots than for healthy ones (Figure 6). For example, in May, just at the beginning of the infestation, a slightly higher CST was observed for the infested plots, whereas the SVIs showed no difference between the two groups. According to bark beetle phenology studies, the flight activity of bark beetles and their successful attack on living trees starts in late spring when the air temperature reaches $16.5^{\circ} \mathrm{C}[9,98]$. The new insight offered by this result is the potential of CST to detect the subtle changes induced by bark beetles at this stage is quite important and promising. Likewise, in July, when the infestation had progressed, and the infested trees were completely stressed, CST maintained its sensitivity in differentiating between healthy and green-attacked sample plots (Figure 6). It is well-known that physiological factors, such as plant water content, can control the temperature of plants through the stomatal transpiration process [35]. Therefore, the distinct variation in CST between healthy and infested plots is attributed to differences in the measured leaf traits, in particular, leaf water content. As depicted in Figure 4, the amount of water content was significantly lower $(p<0.05)$ in the infested plots than in the healthy ones. This may be attributed to the spores of fungi and the drilling activities of the beetle itself that affect the living cells in the phloem and xylem and, therefore, disrupt the flow of water and cause stomatal closure in infested trees [21]. This result further confirms our earlier finding [99] showing a decrease of foliar biochemical properties (chlorophyll and nitrogen concentration) in trees infested by bark beetles (I. typographus, L.) at the green attack stage. Likewise, our findings are in agreement with [22], who studied the impact of a similar species (the mountain pine beetle, Dendroctonus spp.) on leaf water content using hyperspectral data. Infested trees tend to close their stomata to prevent further water loss and hydraulic failure [100]. This stomatal closure will temporarily offset xylem cavitation and cause damage to the photosynthetic apparatus [101]. However, this behaviour leads to other physiological changes in the infested trees, such as a decrease in the transpiration cooling process and, therefore, an increase in leaf surface temperature. Over time, this will affect the process of photosynthesis and cause a change in foliar colour [102]. These findings match those observed in earlier studies that the TCI index retrieved from the Landsat 7 ETM thermal band could detect areas under mountain pine beetle (Dendroctonus spp.) green attack [28].

In August, when the infestation had progressed and the subsequent degradation of the needles could be observed in the field (the infested trees developed stress symptoms by turning their needles' colour from green to yellow to red-brown), the variation of SVIs became more evident between healthy and infested plots. CST, Cigreen, NLI and BGI were shown to have the potential to detect the infested trees at that time. However, for effective management, identifying infested trees at that stage is too late, because the beetles will have already left the infested trees, and logging operations will not have any effect on the population dynamics of the beetles at that time anymore $[9,20,103]$.

In addition to the temporal variation, we also observed that CST improved discrimination between healthy and infested plots when using PCA analysis for all dates considered in this study (Figure 7). In May, when the PCA model was built based on optical data only, the two groups of sample plots had mixed scattering and exhibited an apparent overlap, whereas, when CST was included into the model the healthy plots were separated from the infested ones. This indicates the increased sensitivity of Landsat- 8 TIR data to changes at canopy level induced by bark beetle at a very early stage in May. One possible reason for such sensitivity of CST to spruce bark beetle infestation in May could be due to the nature of spruce bark beetle outbreaks, which generally occur over the course of several years. In other words, the healthy trees are always surrounded by other healthy trees, while, for infested trees in most cases, the infestation occurs close to the previous year's infestation [104]. Therefore, the open areas and dead trees around newly infested trees can lead to an increase in surface temperature. To confirm this, we further analysed and calculated the CST for different habitat types in the landscape. To do this, a habitat map obtained from the national park administration was used to extract the CST for 
each habitat type [105]. As can be observed from Figure 9, the results revealed that clear-cut areas, followed by lying dead-wood and standing dead-wood areas, had the highest CST for all three months. In contrast, mixed stands showed the lowest CST. This is supported by Peterson et al. [106] who found that forest structure (i.e. canopy closure) is negatively correlated with simulated thermal data from the Thematic Mapper Simulator (TMS).

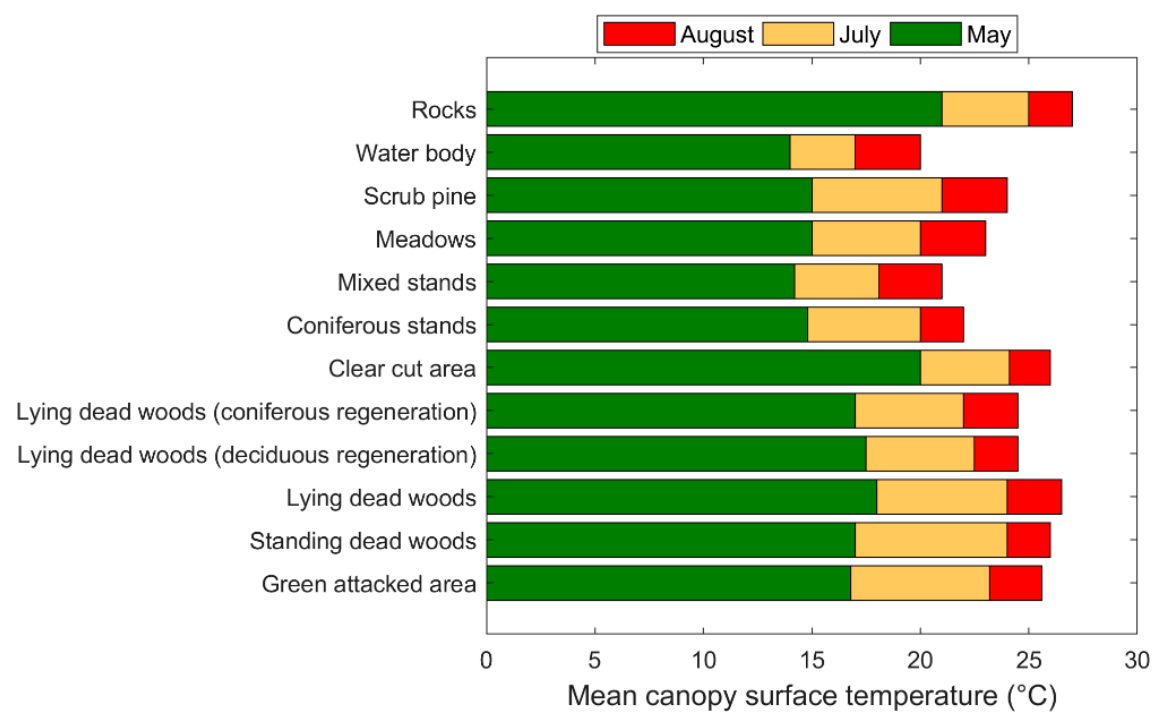

Figure 9. Mean canopy surface temperature over different habitat classes in the Bavarian Forest National Park, 2016. The graph shows that standing dead-wood, lying dead-wood, clear-cut, and rocky areas recorded high surface temperature comparing to other forest classes.

Similarly, Junttila et al. [107] and Hais and Kučera [27] have shown that higher surface temperatures were detected in dead-wood stands and clear-cut areas, respectively. Furthermore, a water body had the lowest CST, which supports the hypothesis that more moisture in healthy tree needles decreased their surface temperature. This also corresponded with our in situ measurements that showed green-attacked trees had lower water content and more closed stomata than healthy trees (Figure 4). The clear-cut area and dead-wood stands had no foliage and, thus, no leaf surface area for evapotranspiration. This resulted in higher canopy temperatures in the cleared and dead-wood stands than in intact stands.

Moreover, an equally significant aspect of CST was found when used to estimate measured leaf traits (foliar stomatal conductance, chlorophyll fluorescence, and water content) and producing the stress map for the study area (Figure 8). The stress map highlighted the sensitivity of CST for detecting canopies that are stressed by bark beetle green attack. In general, the majority (66\%) of ground truth data were located within the severely stressed class. However, $13 \%$ where falsely located in the healthy class (Table 5). Consequently, CST derived from Landsat-8 TIR data might be used to generate hotspot maps of stressed areas within the forest that show high potential areas of bark beetle green attack. Such maps can provide valuable information to the forest management practice when they aim to control this species and preclude a mass outbreak. Furthermore, such maps can also be used to improve the bark beetle modelling community. For example, in our study and the previous studies by [27] the highest temperature was observed over the dead-wood stands. Such information on the dead-wood stands combined with the less reliable information from green attacked areas can be used to improve the accuracy of predisposition models [108].

\section{Conclusions}

The results of this study showed the potential of CST retrieved from the Landsat 8 TIR band to detect early-stage bark beetle infestation. We further found that the infestation at the green attack 
stage affected the leaf stomatal conductance, chlorophyll fluorescence, and water content. The CST has the highest VIP value for estimating all three leaf traits measured in this study for July. In addition, we found that CST maintained its sensitivity for monitoring and detecting bark beetle infestation before, during and after infestation. In conclusion, our key concept is that we show for the first time that satellite TIR data has a high potential to detect bark beetle green attack and examining the link between the leaf traits and thermal remote sensing data is an important step that further improves our understanding of the relationship between Earth observation data and plant traits for forest areas under bark beetle green attack. It is important to note that TIR images obtained from Landsat- 8 are the only available satellite images that provide data at $30 \mathrm{~m}$ spatial resolution. However, the original data were acquired at $100 \mathrm{~m}$, so the actual footprint of the pixel is larger. Therefore, further research investigating different TIR data with higher spectral and spatial resolution, such as TIR from airborne hyperspectral measurements, may improve the use of thermal imagery for bark beetle green attack detection in Norway spruce forests.

Author Contributions: H.A., R.D., A.K.S., and M.H. conceived and designed the experiment. H.A. analyzed the data and wrote the manuscript. All authors contributed to editing of the manuscript.

Funding: This research received financial support from the EU Erasmus Mundus Salam-2 and was co-founded by Natural Resources Department, Faculty of Geo-Information Science and Earth Observation (ITC), University of Twente, the Netherlands.

Acknowledgments: The author's thanks the Bavarian Forest National Park staff for approving access to the test site and providing field and camping facilities. The authors extend their appreciation for the great support during the laboratory measurements from the GeoScience Laboratory at ITC Faculty, University of Twente.

Conflicts of Interest: The authors declare no conflict of interest.

\section{References}

1. Morris, J.L.; Cottrell, S.; Fettig, C.J.; Hansen, W.D.; Sherriff, R.L.; Carter, V.A.; Clear, J.L.; Clement, J.; DeRose, R.J.; Hicke, J.A.; et al. Managing bark beetle impacts on ecosystems and society: Priority questions to motivate future research. J. Appl. Ecol. 2017, 54, 750-760. [CrossRef]

2. Tchakerian, M.D.; Coulson, R.N. Ecological Impacts of Southern Pine Beetle; Coulson, R.N., Klepzig, K.D., Eds.; Southern Pine Beetle II. Gen. Tech. Rep. SRS-140; US Department of Agriculture Forest Service, Southern Research Station: Asheville, NC, USA, 2011; Volume 140, pp. 223-234.

3. Schelhaas, M.J.; Nabuurs, G.J.; Schuck, A. Natural disturbances in the european forests in the 19th and 20th centuries. Glob. Chang. Biol. 2003, 9, 1620-1633. [CrossRef]

4. Eidmann, H. Impact of bark beetles on forests and forestry in sweden. J. Appl. Entomol. 1992, 114, $193-200$. [CrossRef]

5. Pasztor, F.; Matulla, C.; Rammer, W.; Lexer, M.J. Drivers of the bark beetle disturbance regime in alpine forests in austria. For. Ecol. Manag. 2014, 318, 349-358. [CrossRef]

6. Seidl, R.; Rammer, W.; Jäger, D.; Lexer, M.J. Impact of bark beetle (ips typographus 1.) disturbance on timber production and carbon sequestration in different management strategies under climate change. For. Ecol. Manag. 2008, 256, 209-220. [CrossRef]

7. Lehnert, L.W.; Bässler, C.; Brandl, R.; Burton, P.J.; Müller, J. Conservation value of forests attacked by bark beetles: Highest number of indicator species is found in early successional stages. J. Nat. Conserv. 2013, 21, 97-104. [CrossRef]

8. Müller, J.; Bütler, R. A review of habitat thresholds for dead wood: A baseline for management recommendations in european forests. Eur. J. For. Res. 2010, 129, 981-992. [CrossRef]

9. Wermelinger, B. Ecology and management of the spruce bark beetle ips typographus-A review of recent research. For. Ecol. Manag. 2004, 202, 67-82. [CrossRef]

10. Raffa, K.F.; Grégoire, J.-C.; Staffan Lindgren, B. Chapter 1-natural history and ecology of bark beetles. In Bark Beetles; Vega, F.E., Hofstetter, R.W., Eds.; Academic Press: San Diego, CA, USA, 2015; pp. 1-40.

11. Niemann, K.O.; Visintini, F. Assessment of Potential for Remote Sensing Detection of Bark Beetle-Infested Areas during Green Attack: A Literature Review; Natural Resources Canada, Canadian Forest Service, Pacific Forestry Centre: Victoria, BC, Canada, 2005. 
12. Wulder, M.A.; White, J.C.; Bentz, B.; Alvarez, M.F.; Coops, N.C. Estimating the probability of mountain pine beetle red-attack damage. Remote Sens. Environ. 2006, 101, 150-166. [CrossRef]

13. Coulson, R.N.; Amman, G.D.; Dahlsten, D.L.; DeMars, C., Jr.; Stephen, F. Forest-bark beetle interactions: Bark beetle population dynamics. In Integrated Pest Management in Pine-Bark Beetle Ecosystems; John Wiley \& Sons: New York, NY, USA, 1985; pp. 61-80.

14. Wulder, M.A.; Dymond, C.C.; White, J.C.; Leckie, D.G.; Carroll, A.L. Surveying mountain pine beetle damage of forests: A review of remote sensing opportunities. For. Ecol. Manag. 2006, 221, 27-41. [CrossRef]

15. Filchev, L. An Assessment of European Spruce Bark Beetle Infestation Using WorldView-2 Satellite Data. In Proceedings of the 1st European SCGIS Conference with International Participation Best Practices: Application of GIS Technologies for Conservation of Natural and Cultural Heritage Sites || (SCGIS-Bulgaria, Sofia), Sofia, Bulgaria, 21-23 May 2012; pp. 9-16.

16. Franklin, S.E.; Wulder, M.A.; Skakun, R.S.; Carroll, A.L. Mountain pine beetle red-attack forest damage classification using stratified landsat tm data in british columbia, canada. Photogramm. Eng. Remote Sens. 2003, 69, 283-288. [CrossRef]

17. Hais, M.; Jonášová, M.; Langhammer, J.; Kučera, T. Comparison of two types of forest disturbance using multitemporal landsat tm/etm+ imagery and field vegetation data. Remote Sens. Environ. 2009, 113, 835-845. [CrossRef]

18. Havašová, M.; Bucha, T.; Ferenčík, J.; Jakuš, R. Applicability of a vegetation indices-based method to map bark beetle outbreaks in the high tatra mountains. Ann. For. Res. 2015, 58, 295-310. [CrossRef]

19. Meddens, A.J.H.; Hicke, J.A.; Vierling, L.A.; Hudak, A.T. Evaluating methods to detect bark beetle-caused tree mortality using single-date and multi-date landsat imagery. Remote Sens. Environ. 2013, 132, 49-58. [CrossRef]

20. Wulder, M.A.; White, J.C.; Carroll, A.L.; Coops, N.C. Challenges for the operational detection of mountain pine beetle green attack with remote sensing. For. Chron. 2009, 85, 32-38. [CrossRef]

21. Yamaoka, Y.; Swanson, R.; Hiratsuka, Y. Inoculation of lodgepole pine with four blue-stain fungi associated with mountain pine beetle, monitored by a heat pulse velocity (hpv) instrument. Can. J. For. Res. 1990, 20, 31-36. [CrossRef]

22. Cheng, T.; Rivard, B.; Sánchez-Azofeifa, G.A.; Feng, J.; Calvo-Polanco, M. Continuous wavelet analysis for the detection of green attack damage due to mountain pine beetle infestation. Remote Sens. Environ. 2010, 114, 899-910. [CrossRef]

23. Buitrago Acevedo, M.F.; Groen, T.A.; Hecker, C.A.; Skidmore, A.K. Identifying leaf traits that signal stress in tir spectra. ISPRS J. Photogramm. Remote Sens. 2017, 125, 132-145. [CrossRef]

24. Berni, J.A.J.; Zarco-Tejada, P.J.; Gonzalez-Dugo, V.; Fereres, E. Remote sensing of thermal water stress indicators in peach. Acta Hortic. 2012, 962, 325-331. [CrossRef]

25. Jang, J.D.; Viau, A.A.; Anctil, F. Thermal-water stress index from satellite images. Int. J. Remote Sens. 2006, 27, 1619-1639. [CrossRef]

26. Sepulcre-Cantó, G.; Zarco-Tejada, P.J.; Jiménez-Muñoz, J.; Sobrino, J.; De Miguel, E.; Villalobos, F.J. Detection of water stress in an olive orchard with thermal remote sensing imagery. Agric. For. Meteorol. 2006, 136, 31-44. [CrossRef]

27. Hais, M.; Kučera, T. Surface temperature change of spruce forest as a result of bark beetle attack: Remote sensing and gis approach. Eur. J. For. Res. 2008, 127, 327-336. [CrossRef]

28. Sprintsin, M.; Chen, J.M.; Czurylowicz, P. Combining land surface temperature and shortwave infrared reflectance for early detection of mountain pine beetle infestations in western canada. J. Appl. Remote Sens. 2011, 5, 053566. [CrossRef]

29. Ullah, S.; Skidmore, A.K.; Ramoelo, A.; Groen, T.A.; Naeem, M.; Ali, A. Retrieval of leaf water content spanning the visible to thermal infrared spectra. ISPRS J. Photogramm. Remote Sens. 2014, 93, 56-64. [CrossRef]

30. Buitrago, M.F.; Groen, T.A.; Hecker, C.A.; Skidmore, A.K. Changes in thermal infrared spectra of plants caused by temperature and water stress. ISPRS J. Photogramm. Remote Sens. 2016, 111, 22-31. [CrossRef]

31. Neinavaz, E.; Darvishzadeh, R.; Skidmore, A.K.; Groen, T.A. Measuring the response of canopy emissivity spectra to leaf area index variation using thermal hyperspectral data. Int. J. Appl. Earth Obs. Geoinf. 2016, 53, 40-47. [CrossRef] 
32. Kümmerlen, B.; Dauwe, S.; Schmundt, D.; Schurr, U. Thermography to measure water relations of plant leaves. In Handbook of Computer Vision and Applications; Academic Press: London, UK, 1999; Volume 3, pp. 763-781.

33. Fabre, S.; Lesaignoux, A.; Olioso, A.; Briottet, X. Influence of water content on spectral reflectance of leaves

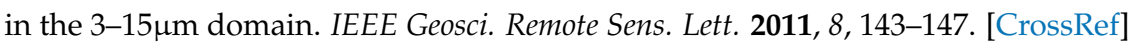

34. Xu, H.; Zhu, S.; Ying, Y.; Jiang, H. Early detection of plant disease using infrared thermal imaging. Opt. Nat. Resour. Agric. Foods. 2006, 6381, 638110. [CrossRef]

35. Oerke, E.; Steiner, U.; Dehne, H.; Lindenthal, M. Thermal imaging of cucumber leaves affected by downy mildew and environmental conditions. J. Exp. Bot. 2006, 57, 2121-2132. [CrossRef]

36. Ni, Z.; Liu, Z.; Huo, H.; Li, Z.-L.; Nerry, F.; Wang, Q.; Li, X. Early water stress detection using leaf-level measurements of chlorophyll fluorescence and temperature data. Remote Sens. 2015, 7, 3232-3249. [CrossRef]

37. Aldea, M.; Hamilton, J.G.; Resti, J.P.; Zangerl, A.R.; Berenbaum, M.R. Indirect effects of insect herbivory on leaf gas exchange in soybean. Plant Cell Environ. 2005, 28, 402-411. [CrossRef]

38. Moller, M.; Alchanatis, V.; Cohen, Y.; Meron, M.; Tsipris, J.; Naor, A.; Ostrovsky, V.; Sprintsin, M.; Cohen, S. Use of thermal and visible imagery for estimating crop water status of irrigated grapevine. J. Exp. Bot. 2007, 58, 827-838. [CrossRef] [PubMed]

39. Hunt, E.R.; Rock, B.N. Detection of changes in leaf water content using near-and middle-infrared reflectances. Remote Sens. Environ. 1989, 30, 43-54.

40. Kim, Y.; Still, C.J.; Hanson, C.V.; Kwon, H.; Greer, B.T.; Law, B.E. Canopy skin temperature variations in relation to climate, soil temperature, and carbon flux at a ponderosa pine forest in central oregon. Agric. For. Meteorol. 2016, 226-227, 161-173. [CrossRef]

41. Gersony, J.T.; Prager, C.M.; Boelman, N.T.; Eitel, J.U.H.; Gough, L.; Greaves, H.E.; Griffin, K.L.; Magney, T.S.; Sweet, S.K.; Vierling, L.A.; et al. Scaling thermal properties from the leaf to the canopy in the alaskan arctic tundra. Arct. Antarct. Alp. Res. 2016, 48, 739-754. [CrossRef]

42. Doughty, C.E.; Field, C.B.; McMillan, A.M. Can crop albedo be increased through the modification of leaf trichomes, and could this cool regional climate? Clim. Chang. 2011, 104, 379-387. [CrossRef]

43. Stoner, W.A.; Miller, P.C. Water relations of plant species in the wet coastal tundra at barrow, alaska. Arct. Alp. Res. 1975, 109-124. [CrossRef]

44. Vanderhoof, M.; Williams, C.A.; Ghimire, B.; Rogan, J. Impact of mountain pine beetle outbreaks on forest albedo and radiative forcing, as derived from moderate resolution imaging spectroradiometer, rocky mountains, USA. J. Geophys. Res. Biogeosci. 2013, 118, 1461-1471. [CrossRef]

45. Schulze, E.-D.; Hall, A. Stomatal responses, water loss and CO2 assimilation rates of plants in contrasting environments. In Physiological Plant Ecology II; Springer: Berlin, Gremany, 1982; pp. 181-230.

46. Pierce, L.L.; Congalton, R.G. A methodology for mapping forest latent heat flux densities using remote sensing. Remote Sens. Environ. 1988, 24, 405-418. [CrossRef]

47. Pierce, L.L.; Running, S.W.; Riggs, G.A. Remote detection of canopy water stress in coniferous forests using the ns001 thematic mapper simulator and the thermal infrared multispectral scanner. PEERS Photogramm. Eng. Remote Sens. 1990, 56, 579-586.

48. Méthy, M.; Olioso, A.; Trabaud, L. Chlorophyll fluorescence as a tool for management of plant resources. Remote Sens. Environ. 1994, 47, 2-9. [CrossRef]

49. Porcar-Castell, A.; Tyystjärvi, E.; Atherton, J.; van der Tol, C.; Flexas, J.; Pfündel, E.E.; Moreno, J.; Frankenberg, C.; Berry, J.A. Linking chlorophyll a fluorescence to photosynthesis for remote sensing applications: Mechanisms and challenges. J. Exp. Bot. 2014, 65, 4065-4095. [CrossRef] [PubMed]

50. McFarlane, J.; Watson, R.D.; Theisen, A.F.; Jackson, R.D.; Ehrler, W.; Pinter, P.; Idso, S.B.; Reginato, R. Plant stress detection by remote measurement of fluorescence. Appl. Opt. 1980, 19, 3287-3289. [CrossRef] [PubMed]

51. Campbell, P.; Middleton, E.; McMurtrey, J.; Chappelle, E. Assessment of vegetation stress using reflectance or fluorescence measurements. J. Environ. Qual. 2007, 36, 832-845. [CrossRef] [PubMed]

52. Heurich, M.; Beudert, B.; Rall, H.; Křenová, Z. National parks as model regions for interdisciplinary long-term ecological research: The bavarian forest and šumavá national parks underway to transboundary ecosystem research. In Long-Term Ecological Research; Springer: Berlin/Heidelberg, Germany, 2010; pp. 327-344. 
53. Bässler, C.; Förster, B.; Moning, C.; Müller, J. The bioklim-project: Biodiversity research between climate change and wilding in a temperate montane forest-The conceptual framework. Waldökologie Landschaftsforschung und Naturschutz 2008, 7, 21-33.

54. Cailleret, M.; Heurich, M.; Bugmann, H. Reduction in browsing intensity may not compensate climate change effects on tree species composition in the bavarian forest national park. For. Ecol. Manag. 2014, 328, 179-192. [CrossRef]

55. Ali, A.M.; Darvishzadeh, R.; Skidmore, A.K.; Duren, I.v.; Heiden, U.; Heurich, M. Estimating leaf functional traits by inversion of prospect: Assessing leaf dry matter content and specific leaf area in mixed mountainous forest. Int. J. Appl. Earth Obs. Geoinf. 2016, 45, 66-76. [CrossRef]

56. Gitelson, A.A.; Buschmann, C.; Lichtenthaler, H.K. The chlorophyll fluorescence ratio $\mathrm{f} 735 / \mathrm{f} 700$ as an accurate measure of the chlorophyll content in plants. Remote Sens. Environ. 1999, 69, 296-302. [CrossRef]

57. Waring, R.H. Estimating forest growth and efficiency in relation to canopy leaf area. Adv. Ecol. Res. 1983, 13, 327-354.

58. Colombo, R.; Meroni, M.; Marchesi, A.; Busetto, L.; Rossini, M.; Giardino, C.; Panigada, C. Estimation of leaf and canopy water content in poplar plantations by means of hyperspectral indices and inverse modeling. Remote Sens. Environ. 2008, 112, 1820-1834. [CrossRef]

59. Adler-Golden, S.M.; Matthew, M.W.; Bernstein, L.S. Atmospheric correction for Short-wave spectral imagery based on MODTRAN 4[C]. Proc. SPIE 1999, 3753, 61-70. [CrossRef]

60. FLAASH Module. Atmospheric Correction Module: QUAC and FLAASH User's Guide; Version 4.7; ITT Visual Information Solutions: Boulder, CO, USA, 2009; p. 44.

61. Eitel, J.U.; Gessler, P.E.; Smith, A.M.; Robberecht, R. Suitability of existing and novel spectral indices to remotely detect water stress in populus spp. For. Ecol. Manag. 2006, 229, 170-182. [CrossRef]

62. Abdullah, H.; Skidmore, A.K.; Darvishzadeh, R.; Heurich, M.; Pettorelli, N.; Disney, M. Sentinel-2 accurately maps green-attack stage of european spruce bark beetle (ips typographus, 1.) compared with landsat-8. Remote Sens. Ecol. Conserv. 2018. [CrossRef]

63. Atzberger, C.; Richter, K.; Vuolo, F.; Darvishzadeh, R.; Schlerf, M. Why confining to vegetation indices? Exploiting the potential of improved spectral observations using radiative transfer models. In Proceedings of the Remote Sensing for Agriculture, Ecosystems, and Hydrology XIII, 19-21 September 2011; p. 81740Q.

64. Malenovsky, Z.; Ufer, C.; Lhotáková, Z.; Clevers, J.G.; Schaepman, M.E.; Albrechtová, J.; Cudlín, P. A new hyperspectral index for chlorophyll estimation of a forest canopy: Area under curve normalised to maximal band depth between 650-725 nm. EARSeL eProc. 2006, 5, 161-172.

65. Misurec, J.; Kopacková, V.; Lhotáková, Z.; Albrechtova, J.; Hanus, J.; Weyermann, J.; Entcheva-Campbell, P. Utilization of hyperspectral image optical indices to assess the norway spruce forest health status. J. Appl. Remote Sens. 2012, 6, 063545.

66. Zhang, F.; Zhou, G. Estimation of canopy water content by means of hyperspectral indices based on drought stress gradient experiments of maize in the north plain china. Remote Sens. 2015, 7, 15203-15223. [CrossRef]

67. Hunt, E.R.; Daughtry, C.; Eitel, J.U.; Long, D.S. Remote sensing leaf chlorophyll content using a visible band index. Agron. J. 2011, 103, 1090-1099. [CrossRef]

68. Escadafal, R.; Belghit, A.; Ben-Moussa, A. Indices spectraux pour la télédétection de la dégradation des milieux naturels en Tunisie aride. In Proceedings of the Actes du 6ème Symposium international sur les mesures physiques et signatures en télédétection, Val d’Isère, France, 17-24 January 1994; pp. 253-259.

69. Tucker, C.J.; Elgin Jr, J.H.; McMurtrey Iii, J.; Fan, C. Monitoring corn and soybean crop development with hand-held radiometer spectral data. Remote Sens. Environ. 1979, 8, 237-248. [CrossRef]

70. Bannari, A.; Morin, D.; Bonn, F.; Huete, A.R. A review of vegetation indices. Remote Sens. Rev. 1995, 13, 95-120. [CrossRef]

71. Ceccato, P.; Gobron, N.; Flasse, S.; Pinty, B.; Tarantola, S. Designing a spectral index to estimate vegetation water content from remote sensing data: Part 1: Theoretical approach. Remote Sens. Environ. 2002, 82, 188-197. [CrossRef]

72. Gitelson, A.A.; Kaufman, Y.J.; Merzlyak, M.N. Use of a green channel in remote sensing of global vegetation from eos-modis. Remote Sens. Environ. 1996, 58, 289-298. [CrossRef]

73. Gobron, N.; Pinty, B.; Verstraete, M.M.; Widlowski, J.-L. Advanced vegetation indices optimized for up-coming sensors: Design, performance, and applications. IEEE Trans. Geosci. Remote Sens. 2000, 38, 2489-2505. 
74. Cohen, W.B. Response of vegetation indices to changes in three measures of leaf water stress. Photogramm. Eng. Remote Sens. 1991, 57, 185-202.

75. Goel, N.S.; Qin, W. Influences of canopy architecture on relationships between various vegetation indices and lai and fpar: A computer simulation. Remote Sens. Rev. 1994, 10, 309-347. [CrossRef]

76. Metternicht, G. Vegetation indices derived from high-resolution airborne videography for precision crop management. Int. J. Remote Sens. 2003, 24, 2855-2877. [CrossRef]

77. Fensholt, R.; Sandholt, I. Derivation of a shortwave infrared water stress index from modis near- and shortwave infrared data in a semiarid environment. Remote Sens. Environ. 2003, 87, 111-121. [CrossRef]

78. Pinder, J.E.; McLeod, K.W. Indications of relative drought stress in longleaf pine from thematic mapper data. Photogramm. Eng. Remote Sens. 1999, 65, 495-501.

79. Tucker, C.J. Red and photographic infrared linear combinations for monitoring vegetation. Remote Sens. Environ. 1979, 8, 127-150. [CrossRef]

80. Bannari, A.; Asalhi, H.; Teillet, P. Transformed difference vegetation index (TDVI) for vegetation cover mapping. In Proceedings of the IEEE International Geoscience and Remote Sensing Symposium (IGARSS '02), Toronto, ON, Canada, 24-28 June 2002; Volume 5.

81. Qin, Z.; Karnieli, A.; Berliner, P. A mono-window algorithm for retrieving land surface temperature from landsat tm data and its application to the israel-egypt border region. Int. J. Remote Sens. 2001, 22, 3719-3746. [CrossRef]

82. Markham, B.L.; Barker, J.L. Landsat MSS and TM Post-Calibration Dynamic Ranges, Exoatmospheric Reflectances and at-Satellite Temperatures. EOSAT Landsat Tech. Notes. 1986, 1, 3-8.

83. Liu, L.; Zhang, Y. Urban heat island analysis using the landsat tm data and aster data: A case study in hong kong. Remote Sens. 2011, 3, 1535-1552. [CrossRef]

84. Zhang, J.; Wang, Y.; Li, Y. A c++ program for retrieving land surface temperature from the data of landsat tm/etm+ band6. Comput. Geosci. 2006, 32, 1796-1805. [CrossRef]

85. Gartland, L. Heat Islands: Understanding and Mitigating Heat in Urban Areas; Earthscan: London, UK, 2008.

86. Snyder, W.C.; Wan, Z.; Zhang, Y.; Feng, Y.-Z. Classification-based emissivity for land surface temperature measurement from space. Int. J. Remote Sens. 1998, 19, 2753-2774. [CrossRef]

87. Dozier, J.; Warren, S.G. Effect of viewing angle on the infrared brightness temperature of snow. Water Resour. Res. 1982, 18, 1424-1434. [CrossRef]

88. Vlassova, L.; Pérez-Cabello, F.; Mimbrero, M.; Llovería, R.; García-Martín, A. Analysis of the relationship between land surface temperature and wildfire severity in a series of landsat images. Remote Sens. 2014, 6, 6136-6162. [CrossRef]

89. Van de Griend, A.; Owe, M. On the relationship between thermal emissivity and the normalized difference vegetation index for natural surfaces. Int. J. Remote Sens. 1993, 14, 1119-1131. [CrossRef]

90. Valor, E.; Caselles, V. Mapping land surface emissivity from ndvi: Application to european, african, and south american areas. Remote Sens. Environ. 1996, 57, 167-184. [CrossRef]

91. Carlson, T.N.; Ripley, D.A. On the relation between ndvi, fractional vegetation cover, and leaf area index. Remote Sens. Environ. 1997, 62, 241-252. [CrossRef]

92. Sobrino, J.A.; Jiménez-Muñoz, J.C.; Sòria, G.; Romaguera, M.; Guanter, L.; Moreno, J.; Plaza, A.; Martínez, P. Land surface emissivity retrieval from different vnir and tir sensors. IEEE Trans. Geosci. Remote Sens. 2008, 46, 316-327. [CrossRef]

93. Sun, Q.; Tan, J.; Xu, Y. An erdas image processing method for retrieving lst and describing urban heat evolution: A case study in the pearl river delta region in south china. Environ. Earth Sci. 2010, 59, 1047-1055. [CrossRef]

94. Farrés, M.; Platikanov, S.; Tsakovski, S.; Tauler, R. Comparison of the variable importance in projection (vip) and of the selectivity ratio (sr) methods for variable selection and interpretation. J. Chemom. 2015, 29, 528-536. [CrossRef]

95. Wold, S.; Sjöström, M.; Eriksson, L. Pls-regression: A basic tool of chemometrics. Chemom. Intell. Lab. Syst. 2001, 58, 109-130. [CrossRef]

96. Chong, I.-G.; Jun, C.-H. Performance of some variable selection methods when multicollinearity is present. Chemom. Intell. Lab. Syst. 2005, 78, 103-112. [CrossRef]

97. Maitra, S.; Yan, J. Principle component analysis and partial least squares: Two dimension reduction techniques for regression. Appl. Multivar. Stat. Models 2008, 79, 79-90. 
98. Lobinger, G. Die lufttemperatur als limitierender faktor für die schwärmaktivität zweier rindenbrütender fichtenborkenkäferarten, lps typographus 1. Undpityogenes chalcographus 1. (col., scolytidae). Anzeiger für Schädlingskunde 1994, 67, 14-17. [CrossRef]

99. Abdullah, H.; Darvishzadeh, R.; Skidmore, A.K.; Groen, T.A.; Heurich, M. European spruce bark beetle (ips typographus, 1.) green attack affects foliar reflectance and biochemical properties. Int. J. Appl. Earth Obs. Geoinf. 2018, 64, 199-209. [CrossRef]

100. Ewers, B.; Mackay, D.; Samanta, S. Interannual consistency in canopy stomatal conductance control of leaf water potential across seven tree species. Tree Physiol. 2007, 27, 11-24. [CrossRef]

101. Chaves, M.M.; Maroco, J.P.; Pereira, J.S. Understanding plant responses to drought-From genes to the whole plant. Funct. Plant Biol. 2003, 30, 239-264. [CrossRef]

102. Larcher, W. Physiological Plant Ecology: Ecophysiology and Stress Physiology of Functional Groups; Springer Science \& Business Media: Berlin/Heidelberg, Germany; Academic Press: New York, NY, USA, 2003.

103. Fahse, L.; Heurich, M. Simulation and analysis of outbreaks of bark beetle infestations and their management at the stand level. Ecol. Model. 2011, 222, 1833-1846. [CrossRef]

104. Lausch, A.; Fahse, L.; Heurich, M. Factors affecting the spatio-temporal dispersion of ips typographus (1.) in bavarian forest national park: A long-term quantitative landscape-level analysis. For. Ecol. Manag. 2011, 261, 233-245. [CrossRef]

105. Dupke, C.; Bonenfant, C.; Reineking, B.; Hable, R.; Zeppenfeld, T.; Ewald, M.; Heurich, M. Habitat selection by a large herbivore at multiple spatial and temporal scales is primarily governed by food resources. Ecography 2017, 40, 1014-1027. [CrossRef]

106. Peterson, D.L.; Westman, W.E.; Stephenson, N.J.; Ambrosia, V.G.; Brass, J.A.; Spanner, M.A. Analysis of forest structure using thematic mapper simulator data. IEEE Trans. Geosci. Remote Sens. 1986, GE-24, 113-121. [CrossRef]

107. Junttila, S.; Vastaranta, M.; Hämäläinen, J.; Latva-Käyrä, P.; Holopainen, M.; Hernández Clemente, R.; Hyyppä, H.; Navarro-Cerrillo, R.M. Effect of forest structure and health on the relative surface temperature captured by airborne thermal imagery-Case study in norway spruce-dominated stands in southern finland. Scand. J. For. Res. 2016, 32, 154-165. [CrossRef]

108. Netherer, S.; Nopp-Mayr, U. Predisposition assessment systems (pas) as supportive tools in forest management-Rating of site and stand-related hazards of bark beetle infestation in the high tatra mountains as an example for system application and verification. For. Ecol. Manag. 2005, 207, 99-107. [CrossRef]

(C) 2019 by the authors. Licensee MDPI, Basel, Switzerland. This article is an open access article distributed under the terms and conditions of the Creative Commons Attribution (CC BY) license (http:/ / creativecommons.org/licenses/by/4.0/). 